University of South Florida

DIGITAL COMMONS

Digital Commons @ University of

@ UNIVERSITY OF SOUTH FLORIDA

South Florida

$1-1-2014$

\title{
2014 Accountability Report USF Tampa
}

USF

Follow this and additional works at: https://digitalcommons.usf.edu/usf_accountability_reports

\section{Scholar Commons Citation}

USF, "2014 Accountability Report USF Tampa" (2014). USF Accountability Reports. 44.

https://digitalcommons.usf.edu/usf_accountability_reports/44

This Article is brought to you for free and open access by the USF Archives at Digital Commons @ University of South Florida. It has been accepted for inclusion in USF Accountability Reports by an authorized administrator of Digital Commons @ University of South Florida. For more information, please contact digitalcommons@usf.edu. 


\section{3-14 \\ Annual Accountability Report

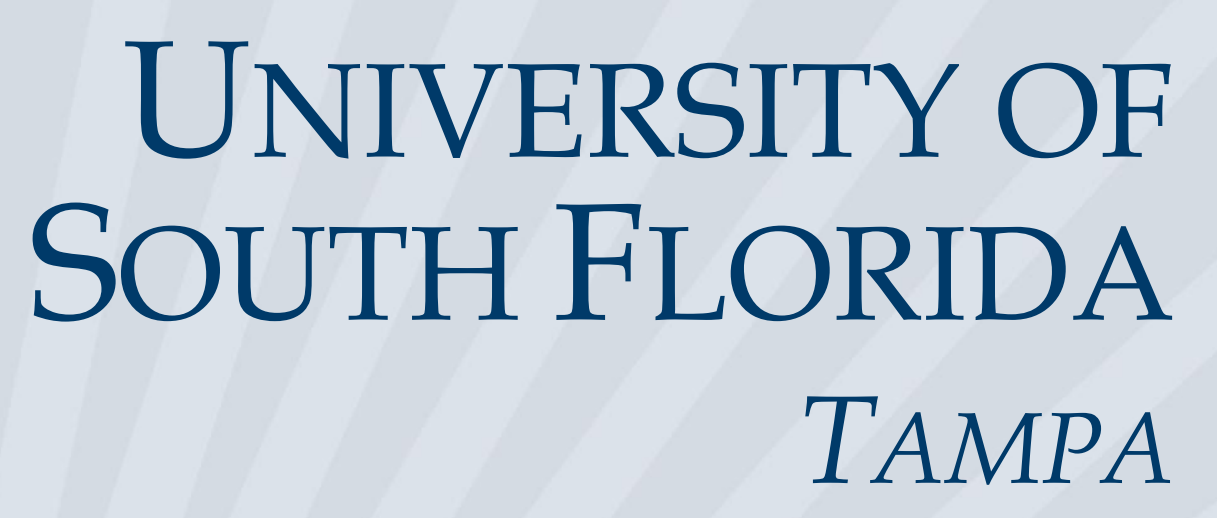

STATE UNIVERSITY SYSTEM of FLORIDA Board of Governors 


\section{TABLE OF CONTENTS}

\section{EXECUTIVE SUMMARY}

DASHBOARD

KEY ACHIEVEMENTS

NARRATIVE p. 2

p. 5

p. 6

\section{DATA TABLES}

SECTION 1. FINANCIAL RESOURCES

p. 13

SECTION 2. PERSONNEL

p. 18

SECTION 3. ENROLLMENT

p. 19

SECTION 4. UNDERGRADUATE EDUCATION

p. 23

SECTION 5. GRADUATE EDUCATION

p. 32

SECTION 6. RESEARCH \& ECONOMIC DEVELOPMENT

p. 35 


\section{Dashboard}

\begin{tabular}{|c|c|c|c|c|c|c|c|c|}
\hline $\begin{array}{l}\text { Headcount } \\
\text { Enrollments }\end{array}$ & $\begin{array}{l}\text { Fall } \\
2013\end{array}$ & $\begin{array}{l}\% \\
\text { Total }\end{array}$ & $\begin{array}{l}2012-2013 \\
\% \text { Change }\end{array}$ & \multicolumn{3}{|c|}{ Degree Programs Offered } & \multicolumn{2}{|c|}{2012 Carnegie Classifications } \\
\hline Total & 41,688 & $100 \%$ & $1 \%$ & \multicolumn{2}{|c|}{ TOTAL (as of Spring 2014) } & 235 & \multirow{2}{*}{ Basic } & \multirow{2}{*}{$\begin{array}{l}\text { Research Universities } \\
\text { (very high research activity) }\end{array}$} \\
\hline White & 22.846 & $55 \%$ & $-3 \%$ & \multicolumn{2}{|l|}{ Baccalaureate } & 83 & & \\
\hline Hispanic & 7,190 & $17 \%$ & $5 \%$ & \multicolumn{2}{|l|}{ Master's \& Specialist's } & 106 & \multirow{2}{*}{$\begin{array}{l}\text { UNDERGRADUATE } \\
\text { PROGRAMS }\end{array}$} & \multirow{2}{*}{$\begin{array}{l}\text { Balanced arts \& sciences, } \\
\text { professions, high graduate }\end{array}$} \\
\hline Black & 4,325 & $10 \%$ & $-2 \%$ & \multicolumn{2}{|l|}{ Research Doctorate } & 42 & & \\
\hline Other & 7,327 & $18 \%$ & $14 \%$ & \multicolumn{2}{|l|}{ Professional Doctorate } & 4 & \multirow{2}{*}{$\begin{array}{l}\text { GRADUATE } \\
\text { PROGRAMS }\end{array}$} & \multirow{2}{*}{$\begin{array}{l}\text { Comprehensive doctoral } \\
\text { with medical/veterinary }\end{array}$} \\
\hline Full-Time & 28,803 & $69 \%$ & $1 \%$ & \multirow{2}{*}{$\begin{array}{l}\text { Faculty } \\
\text { (Fall 2013) }\end{array}$} & \multirow{2}{*}{$\begin{array}{l}\text { Full- } \\
\text { Time }\end{array}$} & \multirow{2}{*}{$\begin{array}{l}\text { Part- } \\
\text { Time }\end{array}$} & & \\
\hline Part-Time & 12,885 & $31 \%$ & $2 \%$ & & & & \multirow{2}{*}{$\begin{array}{l}\text { SIZE \& } \\
\text { SETTING }\end{array}$} & \multirow{2}{*}{$\begin{array}{c}\text { Large four-year, primarily } \\
\text { nonresidential }\end{array}$} \\
\hline Undergraduate & 30,391 & $73 \%$ & $0 \%$ & TOTAL & 1,850 & 610 & & \\
\hline Graduate & 9,640 & $23 \%$ & $6 \%$ & Tenure \& Ten. Track & 1,008 & 38 & \multirow{2}{*}{$\begin{array}{l}\text { COMMUNITY } \\
\text { ENGAGEMENT }\end{array}$} & \multirow{2}{*}{$\begin{array}{l}\text { Curricular Engagement and } \\
\text { Outreach and Partnerships }\end{array}$} \\
\hline Unclassified & 1,657 & $4 \%$ & $0 \%$ & Non-Tenured Faculty & 842 & 572 & & \\
\hline
\end{tabular}

\section{DEGREE PRODUCTIVITY AND PROGRAM EFFICIENCY}

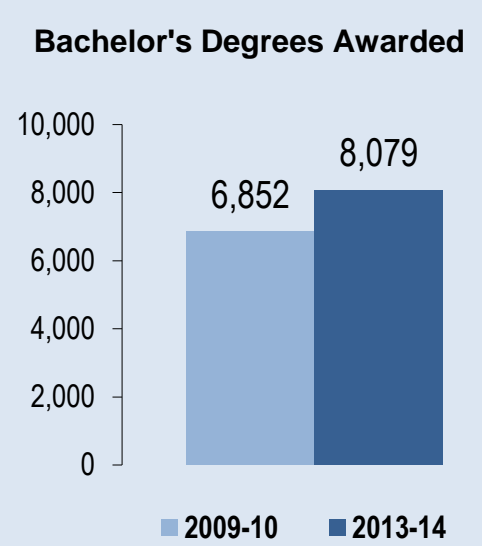

\section{Graduate Degrees Awarded}

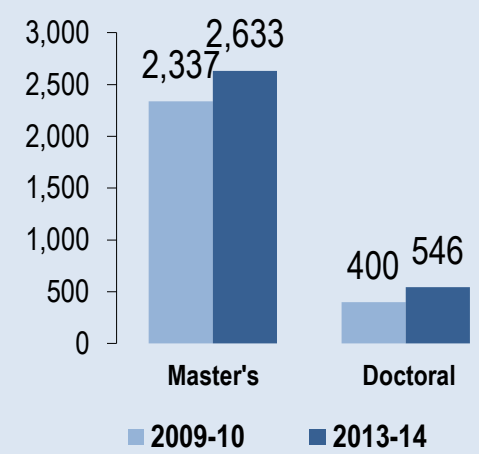

\section{Bachelor's Degrees by Group}

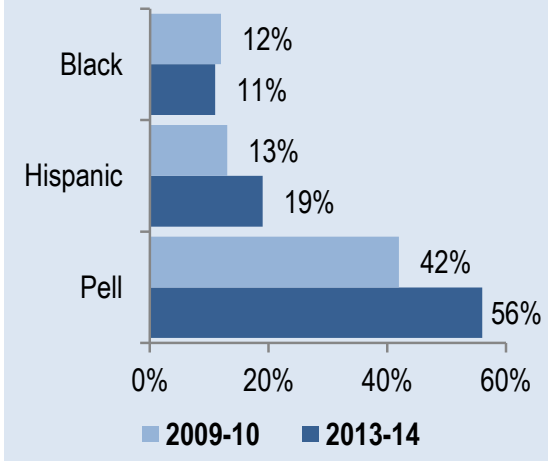

Bachelor's Degrees Without Excess Hours

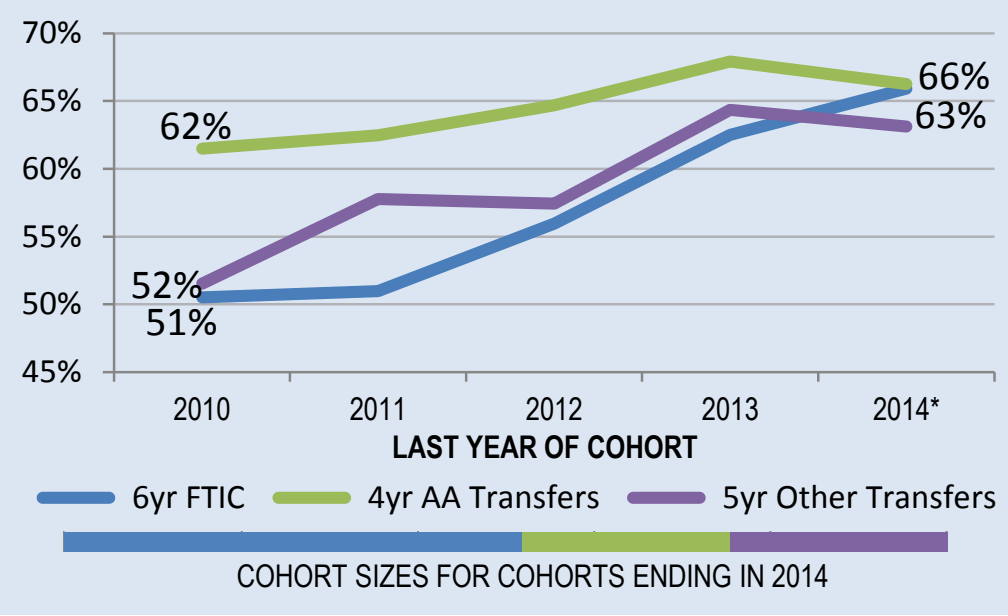

\section{Graduation Rates by Student Type}




\section{Dashboard}

\section{DEGREES AWARDED IN PROGRAMS OF STRATEGIC EMPHASIS}
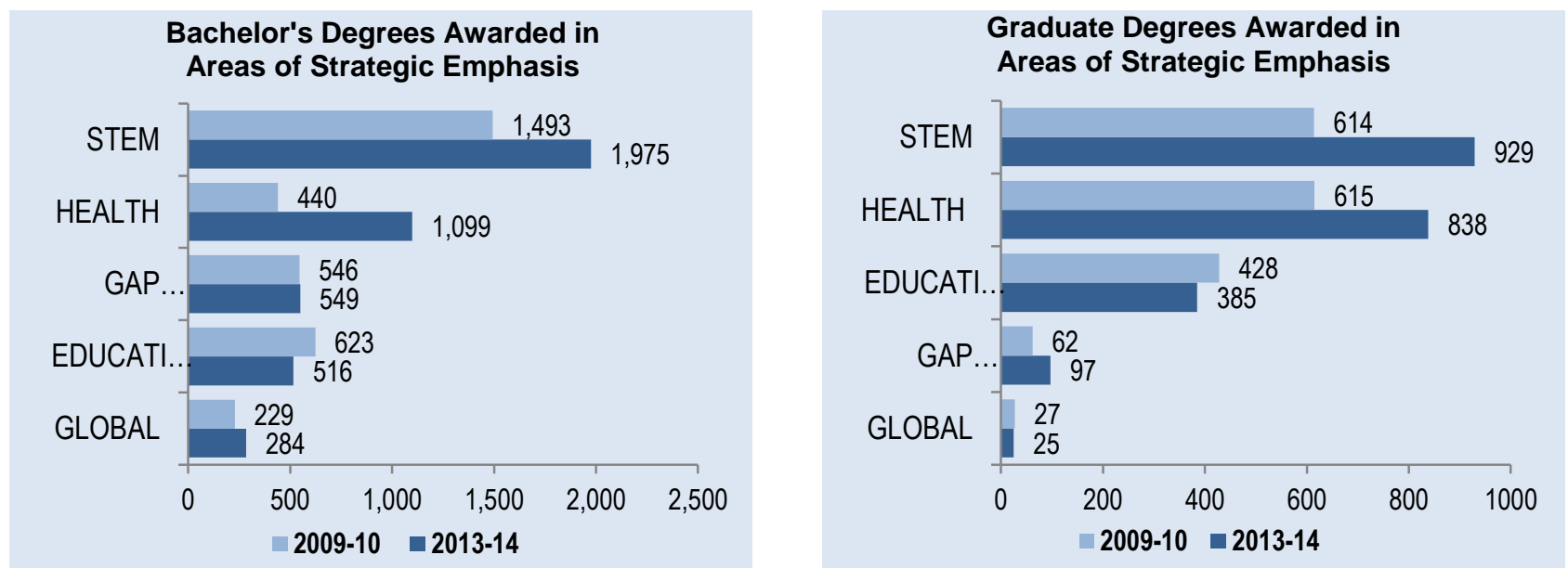

* Security/Emergency Services and Globalization disciplines are described in more detail on pages 11-12.

\section{RESEARCH AND COMMERCIALIZATION ACTIVITY}

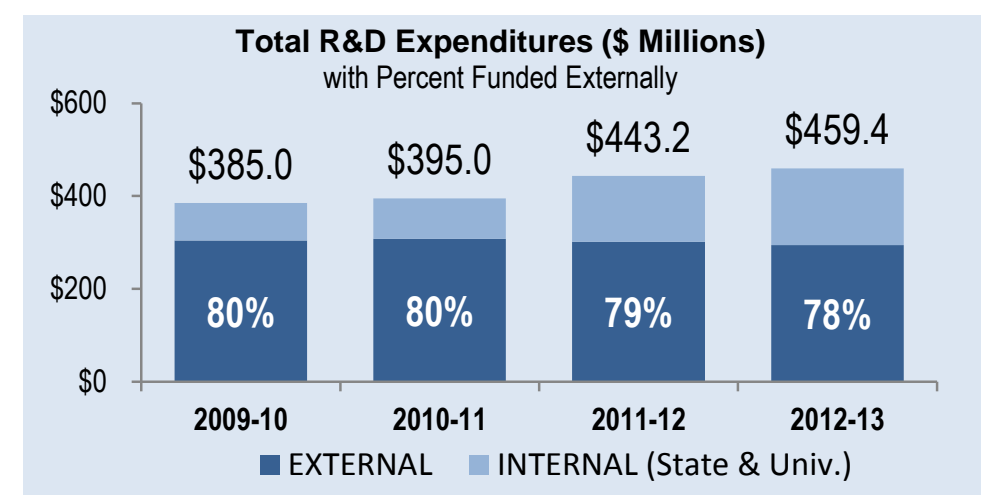

RESOURCES

\begin{tabular}{|c|c|c|c|c|c|}
\hline \multirow{2}{*}{$\$ 15,000$} & \multicolumn{4}{|c|}{ Appropriated Funding Per Actual US FTE } & \multirow{3}{*}{$\$ 13,545$} \\
\hline & $\$ 10,970$ & $\$ 11,278$ & $\$ 11,619$ & $\$ 10,455$ & \\
\hline$\$ 10,000$ & & & & & \\
\hline$\$ 5,000$ & $67 \%$ & $63 \%$ & $58 \%$ & & $53 \%$ \\
\hline \$o & $2009-10$ & 2010-11 & 2011-12 & 2012-13 & 2013-14 \\
\hline TOTAL & $\$ 10,970$ & $\$ 11,278$ & $\$ 11,619$ & $\$ 10,455$ & $\$ 13,545$ \\
\hline$=$ TUITION & $\$ 3,620$ & $\$ 4,156$ & $\$ 4,835$ & $\$ 5,358$ & $\$ 6,333$ \\
\hline - STATE & $\$ 7,351$ & $\$ 7,122$ & $\$ 6,784$ & $\$ 5,097$ & $\$ 7,212$ \\
\hline
\end{tabular}

Note: Tuition is the appropriated budget authority, not the amount actually collected. This tuition data does not include non-instructional local fees. State includes General Revenues, Lottery and Other Trust funds (i.e. Federal Stimulus for 2010-11 and 2011-12 only). Student FTE are actual (not funded) and based on the national definition. 


\section{Dashboard}

\section{POST-GRADUATION METRICS}

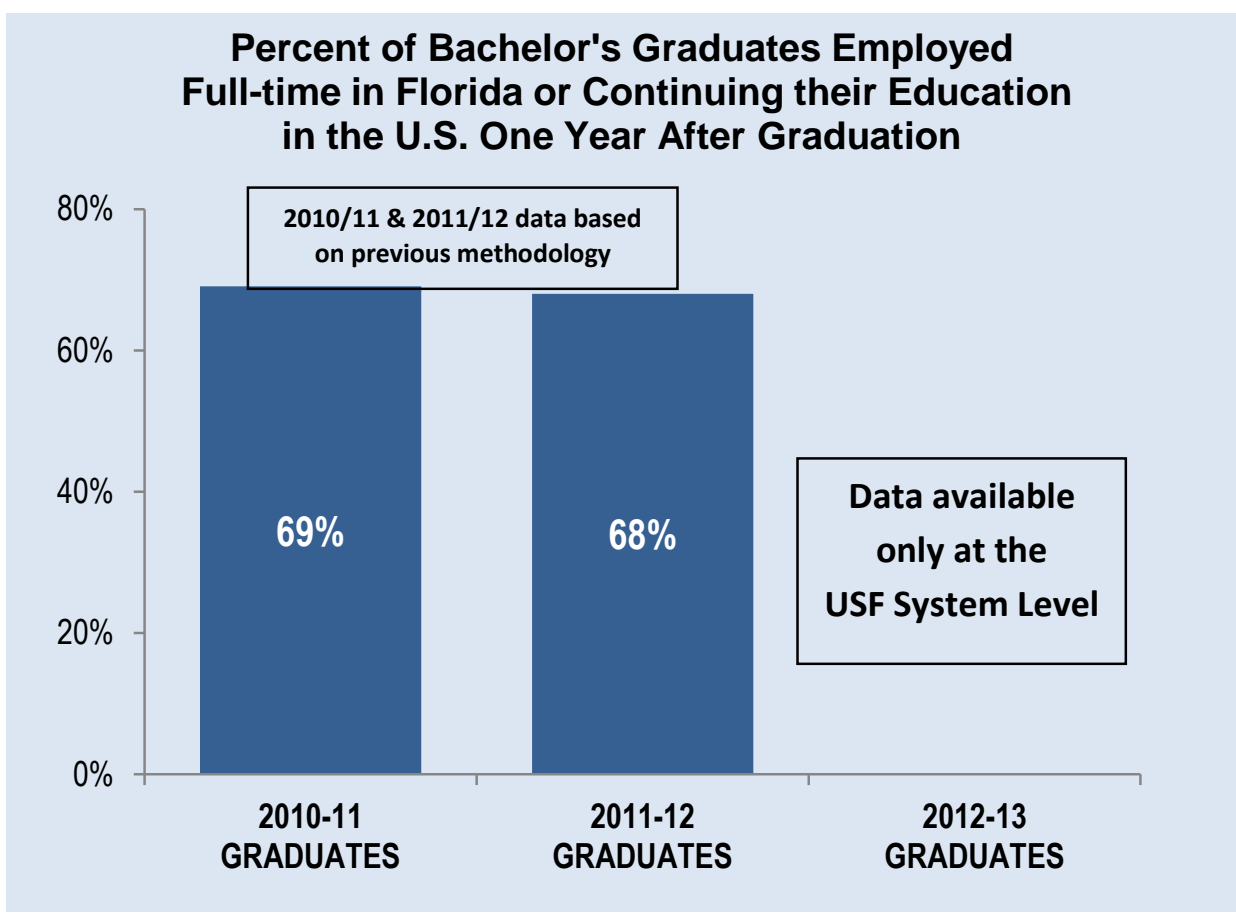

Wages of Full-time Employed in Florida Baccalaureates One Year After Graduation 25th, 50th and 75th Percentiles

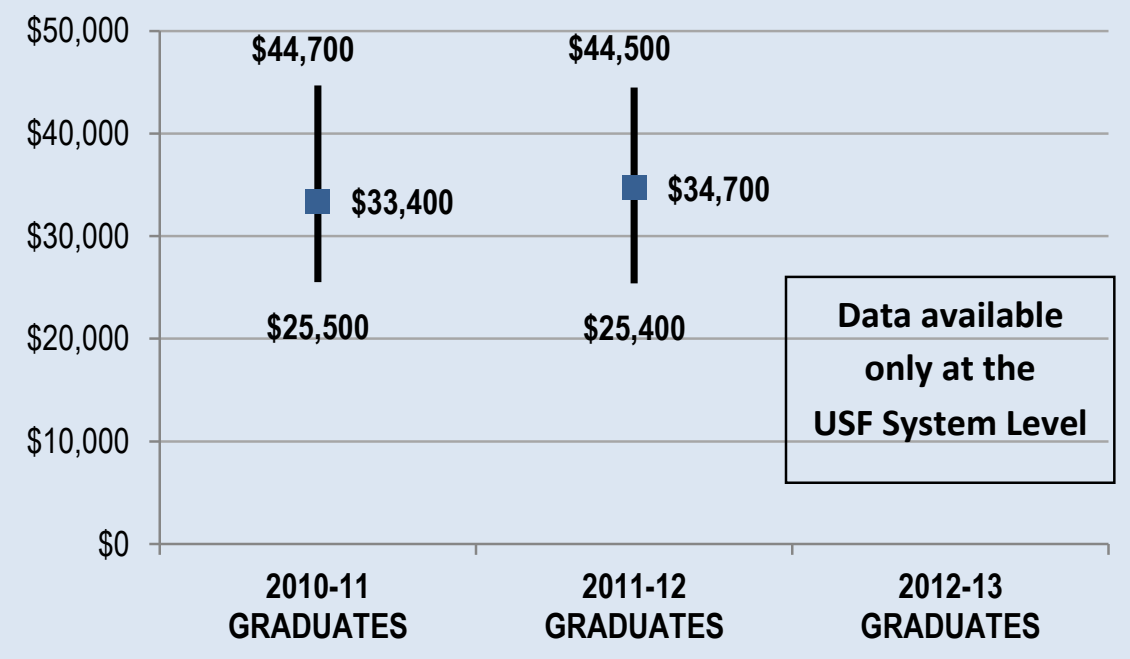




\section{Key Achievements (2013-2014)}

Limit to one page. Please don't include achievements reported last year.

\section{STUDENT AWARDS/ACHIEVEMENTS}

1. The fall 2013 freshman class was the strongest academically in USF's history, with an overall 4.0 GPA and 1200 average SAT score.

2. USF engineering alum David Walker was named to Forbes magazine's 30 Under 30 list, honoring innovators who are "re-inventing the world now."

3. Three USF students earned a Goldwater Scholarship Award, the most prestigious undergraduate award for science and research. Michael Calzadilla, Kaitlin Deutsch and Fiona Kearns are the only 2013 Goldwater Scholars in the State University System of Florida.

\section{FACULTY AWARDS/ACHIEVEMENTS}

1. Six USF faculty members were named Fellows of the American Association for the Advancement of Science - putting USF in the top 10 organizations worldwide for AAAS Fellows.

2. USF Engineering Professor Rajan Sen was one of just three structural engineers to participate in the Jefferson Science Fellowship at the U.S. Department of State.

3. USF Marine Science Associate Professor Mya Breitbart was named one of Popular Science magazine's "Brilliant 10," which recognizes the nation's brightest young scientists.

\section{PROGRAM AWARDS/ACHIEVEMENTS}

1. USF's graduate entrepreneurship program was ranked 13 nationally by Entrepreneur magazine and the Princeton Review. It is the only Florida school that made the list.

2. USF's College of Business was named No. 9 nationally for veterans education by Military Times magazine.

3. U.S. News and World Report named USF's College of Education as one of America's best graduate schools for the $10^{\text {th }}$ consecutive year.

\section{RESEARCH AWARDS/ACHIEVEMENTS}

1. USF's total research expenditures topped $\$ 428$ million, a university record that puts USF at No. 2 in Florida for research expenditures nearly doubling the output of the \#3 ranked state university.

2. USF moved up 10 spots in national research rankings, now No. 43 in the National Science

Foundation's rankings of public and private institutions' research (\#27 among public universities) spending nationwide.

3. USF ranked No. 12 in the world for U.S. utility patents with 95 patents in 2013.

\section{INSTITUTIONAL AWARDS/ACHIEVEMENTS}

1. For the second year in a row, USF was a leader in the Board of Governors' performance-based funding model, coming in at No. 2 in 2013-14 in key measures of student success.

2. USF's graduation rate continues to climb, now at a record high 63 percent for six-years and on pace to reach our goal of $70 \%$ by 2017 .

3. USF had its best fundraising year yet in 2013 , with a record-setting $\$ 113$ million raised in a single year for the USF Unstoppable campaign. The campaign has raised more than $\$ 800$ million toward its $\$ 1$ billion goal.

4. USF was also ranked fifth among the country's most veteran-friendly schools by Military Times' Best for Vets: Colleges 2014 rankings. 


\section{Narrative}

Limit narrative to one page per section (a 9pg max). Arial 11 point font.

\section{Teaching and Learning}

\section{STRENGTHEN QUALITY AND REPUTATION OF ACADEMIC PROGRAMS AND UNIVERSITIES}

At USF, we talk a lot about balancing strategic priorities. With our eyes firmly set on AAU eligibility, we simultaneously work hard on improving Board of Governors' performance-funding metrics and remaining fully engaged with the community. We cheer for research while beating the drum of undergraduate student success and job placement. We reach for rankings. But one theme runs like a current through each of these aims: quality. Without quality, none of it would matter.

Quality is the USF Class of 2017, with an average GPA of 4.0 and SAT score of 1200.

Quality is having three Goldwater Scholars, the only recipients of the coveted undergraduate science award in the State University System of Florida.

Quality is being recognized by Princeton Review as one of the top 75 Best College Values in the country.

Quality is being ranked among the best 300 colleges and universities in the world by the Academic Ranking of World Universities.

Quality is being lauded by the Center for American Progress as one of just three standout universities nationwide in student success development. The Center recognized USF as a leader in providing access to high-quality higher education to those students who need it most.

These are just a few of the examples in one year of our dedication to quality - a dedication that guides every decision we make.

\section{INCREASE DEGREE PRODUCTIVITY AND PROGRAM EFFICIENCY}

Degree productivity and program efficiency comes from a commitment to student success. Rooted at the center of our Strategic Plan, our student success movement has grown from a good idea to transformative campus culture. Our students are performing better than ever before, and they're moving toward graduation and jobs in a timely, productive fashion. Some highlights:

During the 2013-14 academic year, we once again broke institutional records with a 63 percent graduation rate. We fully anticipate breaking that record again in the coming year.

Our first- to second-year retention rate is a point of pride for USF at nearly 90 percent, but we are not yet satisfied. To further improve this metric, we have developed new first-year programs to help students transition from high school to college life. These include new academic foundations curriculum offerings, a common reading experience, and a freshman summer institute (U-First) that provides personal support for first-year students - many of whom are the first in their families to go to college.

Meanwhile, USF's advising services are stronger than ever. We now use a professional team of academic advisers who receive targeted career-guidance training. This ensures that students not only receive top-notch academic advice, but that all advice they are given is geared toward progress to a successful career. 
We are continuing to expand alternative course deliveries, including online learning, to best meet students' needs. Nearly a quarter of our FTE enrollment in 2013-14 was offered via alternative methods of instruction. Students can now complete all their general education courses online. We are also now utilizing a number of new systems, including DegreeWorks and Civitas, to closely monitor students' progress and help them stay on a productive path toward graduation.

Each member of the USF community deserves credit for these gains. When we set about making student success the centerpiece of our Strategic Plan, we did so by making it the responsibility of every person and unit on campus. We set expectations high, and USF continues to rise to the challenge.

\section{INCREASE THE NUMBER OF DEGREES AWARDED IN S.T.E.M. AND OTHER PROGRAMS OF STRATEGIC EMPHASIS}

In 2013-14, 54 percent of USF's undergraduate degrees were in areas of strategic emphasis, including 24 percent in STEM; in graduate degrees, 72 percent were in areas of strategic emphasis, including 29 percent in STEM. This reflects USF's focus on preparing our students for the high-demand jobs of the future.

These jobs include cybersecurity - the subject of one of USF's newest master's degrees under the umbrella of the statewide Florida Center for Cybersecurity. USF's new M.S. in cybersecurity, which includes four concentrations, attracted a strong first cohort of nearly 40 students for its launch in fall 2014.

Additionally, we had a record number of M.D. graduates in 2013-14, with 125 talented new doctors now entering the healthcare workforce across Florida and the nation.

USF's focus on STEM can be seen across campus and at every student level.

One example: the USF Science, Math and Research Technology (SMART) Lab, continues to serve growing numbers of students with innovative teaching practices for gatekeeper courses. In Fall 2013, 3,600 students enrolled in SMART lab courses, experiencing stronger pass-rates than courses using other models. The SMART lab continues to draw national interest through conference invitations and article solicitations.

Building off the success of the SMART lab, USF has now established a new Digital Media Commons in the library. In this new area, which now encompasses the library's entire first floor, students not only have access to the most up-to-date computer workstations 24 hours a day, 5 days a week - but they can also receive training in a variety of digital equipment and software. 


\section{Narrative}

\section{Scholarship, Research and Innovation}

\section{STRENGTHEN QUALITY AND REPUTATION OF SCHOLARSHIP, RESEARCH AND INNOVATION}

USF research continues to make a major impact on Florida as a leader in the study of brain research, aging, heart health, infectious disease, drug discovery, robotics, biometrics, big data, cybersecurity, climate change, coastal biology and ecosystems, among others.

One of 40 public research universities nationwide designated as both "very high research activity" and "community engaged" by the Carnegie Foundation for the Advancement of Teaching, USF is classified in the top tier of research universities, a distinction attained by only 2.3 percent of all universities. USF moved up this year to $43^{\text {rd }}$ in the nation for total research expenditures among all U.S. universities, public or private (\#27 among all public universities), and $2^{\text {nd }}$ in Florida, and was awarded a record $\$ 467 \mathrm{M}$ in research contracts and grants, an increase of nearly $\$ 15 \mathrm{M}$.

During 2013-2014, USF faculty were recognized with 70 AAU, TARU, NRC and other highly prestigious awards, including two Sloan research fellowships, four NSF CAREER awards, six AAAS Fellows, two Core Fulbrights, a AAAS-Lemelson Invention Ambassador and the Rome prize.

In 2013, USF founded the Florida Inventors Hall of Fame to encourage Florida inventors to strive toward the betterment of Florida and society as a whole through continuous, groundbreaking innovation. The inaugural class of six inventors inducted by the U.S. Commissioner for Patents included four from Florida universities (USF, UF, UCF and FAU).

The wider National Academy of Inventors (NAI), also founded at USF, has grown by 70 percent this year to more than 3,000 individual inventor members and fellows spanning more than 200 U.S. universities, governmental entities and nonprofit research institutions. The USF chapter of the NAI has grown from 131 members in 2009 to more than 300 inventors who collectively hold more than 1,750 patents.

\section{INCREASE RESEARCH AND COMMERCIALIZATION ACTIVITY}

USF has cultivated a spirit of entrepreneurship and innovation, aggressively pursuing grants and contracts, promoting interdisciplinary collaboration and working hard to bring scientific discoveries to the market.

As federal funding has waned, USF has proactively worked to increase funding through private partnerships (3.9 percent increase from last year) and state and local government (13.1 percent increase) and to increase both grant proposals submitted by USF researchers (8 percent increase from last year) and dollars requested (14.3 percent increase) - a strategy that led to record-breaking award dollars in 2013-14. 
A global leader in patenting, USF ranks $12^{\text {th }}$ among universities worldwide receiving U.S. utility patents (IPO/NAI 2013) and has ranked in the top 15 for the past 4 years. 2013-14 was also a record-breaking year for USF commercialization activities, with 91 licenses and option agreements negotiated (21 percent increase from the previous year), 113 U.S. patents issued (49 percent increase) and 11 start-up companies created (12 percent increase).

The USF Tampa Bay Technology Incubator (TBTI) grew from 42 to 55 resident and affiliate companies in 2013-14. TBTI companies have created and retained 193 jobs with salaries averaging $\$ 70,000$. Current companies received $\$ 103.7 \mathrm{M}$ in external funding and $\$ 11.6 \mathrm{M}$ in sales revenue for 2013-14.

In November 2013, in partnership with USF's Center for Entrepreneurship, the Florida High Tech Corridor Council (The Corridor) and Hillsborough County, USF launched the Student Innovation Incubator, with 40 student-led companies vying for 15 spots in the first cohort to enter the collaborative, multidisciplinary environment for growing their businesses.

Research is a vital part of the USF experience at every level. Through the Office for Undergraduate Research, students are connected to faculty mentors who help them with inquiries on a variety of topics. During the 2013-14 academic year, more than 2,500 students engaged in some form of monitored research, which enhanced their academic success, retention and job-readiness.

\section{INCREASE COLLABORATION AND EXTERNAL SUPPORT FOR RESEARCH ACTIVITY}

USF research enjoys broad external support. Of USF's total $\$ 428 \mathrm{M}$ in external research funding in 2014 , nearly half came from community partnerships, mostly from private or foundation partners. Currently, USF has more than 200 active collaborative agreements in more than 60 countries with more than 170 institutions around the world, laying the foundation for the development of strengthening and enriching international educational and research experiences for both faculty and students.

The university also has numerous research and health care partnerships with hospitals and not-for-profit organizations in the metropolitan Tampa Bay area that provide for collaboration through shared facilities, faculty and equipment. In addition to partnerships for medical research and training with the $\mathrm{H}$. Lee Moffitt Cancer Center \& Research Institute, Tampa General Hospital, All Children's Hospital, and the James A. Haley Veterans Hospital, USF's affiliate partnerships with Mote Marine Laboratory, Draper Laboratory and others have increased research capacities and economic development. For example, in the Draper Bioengineering Center, housed in the USF Research Park, researchers work on funded projects with global health faculty. New partners continue to relocate to the USF Research Park, such as Lion Biotechnologies, which is developing novel cancer immunotherapies.

Additional external collaborations include working with The Corridor to provide $\$ 100,000$ in support for the Pasco County SMARTstart Incubator Network and partnering with Tampa Bay WaVE to establish the First WaVE Accelerator in downtown Tampa, which has incubated 72 startup companies, created and retained 190 jobs, and raised \$8.4M in outside capital since its launch in March 2013. 


\section{Narrative}

\section{Community and Business Engagement}

\section{STRENGTHEN QUALITY AND REPUTATION OF COMMITMENT TO COMMUNITY AND BUSINESS ENGAGEMENT}

High-impact community and business engagement is another key tenant of USF's Strategic Plan. This is important not only for providing a strong and sustainable future for Florida's economy, but also to retain students and support timely graduation. Students benefit greatly from programs outside the classroom that connect them with future employers and encourage reflection on future goals. Those students who complement their studies with "real world" experiences are also more likely to succeed academically.

USF's Office of Community Engagement and Partnerships promotes engagement through servicelearning, internships and other activities. Service-learning opportunities are now available to students starting with their first year courses and continuing through upper-level and graduate seminars. These activities include recording oral histories, building waste-processing facilities, tutoring elementary school pupils, and many others. In 2013-14, 188 service learning course sections were offered at USF, serving 4,013 students.

The university also helps faculty create courses that bridge classroom and community. In 2013-14, USF held workshops for faculty interested in service learning and "meet-and-greet" sessions with community partners. USF also co-sponsored Service Learning Day as an opportunity for faculty to learn more about these efforts. Mini-grants further supported five faculty members offering service-learning courses.

Students clearly appreciate this commitment, as evidenced by the growing numbers of students who participate each year in the USF Stampede of Service, an annual service day now attended by more than 2,500 students. These students volunteer at more than 40 different sites across Hillsborough County.

Meanwhile, USF's Small Business Development Center at the Muma College of Business works hard to help budding entrepreneurs and established small businesses grow and succeed. This center is Florida's principal provider of small-business assistance, providing one-on-one consulting sessions and seminars to help businesses across the community and the state.

\section{INCREASE LEVELS OF COMMUNITY AND BUSINESS ENGAGEMENT}

During the 2013-14, USF completely revamped its Career Services operation - recognizing the important value of increased engagement on both student success and the institution's reputation. This included the creation of a new Assistant Vice President for Career Services, whose No. 1 job is to secure external partnerships for engagement. Additionally, responsibility for promoting internships was given to a new Director of Internships, to be supervised by the AVP for Career Services.

In the midst of this transformation, high-quality support of engagement activities remained strong as ever. Overall employer attendance at job fairs actually increased by 10 percent, while student attendance 
surged more than 30 percent. Career Services registered 1,750 new employers to the USF Employ-ABull online job database, and more than 9,000 new students registered to use the service.

One of many successful partnership initiatives was welcoming Google to campus to host two Google Talks in the USF College of Engineering. These discussions introduced students to Google's core values and hiring principles that have helped Google earn the No. 1 spot among college graduates for the most desired places to work.

\section{INCREASE COMMUNITY AND BUSINESS WORKFORCE}

USF's maintains a consistent focus on the success of its students not only for the sake of academic achievements, but most importantly to ensure a productive career path after graduation. The university works hard to support Florida's community and business workforce with talented Florida students.

This begins with the USF's Career Services office while students are in the university, but it also occurs with a laser-focus on life beyond graduation.

On campus, USF's Career Services offers regular career and internship fairs to help students make meaningful connections with future employers. In 2013-14, more than 100 employers and nearly 1,000 USF students attended the Part Time and Internship Job Fairs. For the two-day mostly full-time job fair, 274 employers and more than 1,200 students attended. The Accounting profession, always strong enough to warrant its own job fair, hosted 60 employers and 441 students competing for full time and internship positions.

USF Career Services also actively seeks partners across the community who work to keep bright students employed in the Tampa Bay region. This includes a partnership with the Education Connection, a sub-committee of the Tampa Chamber of Commerce. The partnership was created to develop workforce talent, encourage industry-leading research, and inspire meaningful relationships to create one of the most respected communities in the world.

In addition to helping students secure a successful job, USF also works to prepare students for any financial obstacles they may face after they leave campus. Through a new Financial Education Program, which opened in August 2013, USF employs a variety of strategies to help students with a number of financial issues. In 2013-14, the program conducted seminars on budgeting and saving, establishing credit, and reading credit reports. These kinds of seminars served nearly 900 students.

Our "Bull2Bull" program, for instance, connects undergraduate students in group and one-on-one financial counseling services. Another service is an in-person student loan counseling session, where students can learn about loan repayment options, deferments and loan-forgiveness plans with the goal of minimizing potential loan defaults. We follow up with these students six months after graduation, when they begin to repay those loans, to assist with any additional challenges they may have. 


\section{Data Tables (new tables are shown in RED text below)}

\section{FINANCIAL RESOURCES}

Table 1A. Education and General Revenues

Table 1B. Education and General Expenditures

Table 1C. Funding per Student FTE

Table 1D. Other Budget Entities

Table 1E. Voluntary Support of Higher Education

Table 1F. Tuition Differential Fee

\section{PERSONNEL}

Table 2A. Personnel Headcount

\section{ENROLLMENT}

Table 3A. Headcount Enrollment by Student Type

Table 3B. Full-time Equivalent (FTE) Enrollment

Table 3C. Enrollment by Method of Instruction

Table 3D. Headcount Enrollment by Military Status and Student Level

Table 3E. University Access Rate: Undergraduate Enrollment with Pell Grant

\section{UNDERGRADUATE EDUCATION}

Table 4A. Baccalaureate Degree Program Changes in AY 2013-2014

Table 4B. Retention Rates

Table 4C. Full-time, First-Time-in-College (FTIC) Six-Year Graduation Rates

Table 4D. Full- and Part-time FTIC Graduation Rates

Table 4E. AA Transfers Graduation Rates

Table 4F. Other Transfers Graduation Rates

Table 4G. Baccalaureate Degrees Awarded

Table 4H. Baccalaureate Degrees Awarded in Areas of Strategic Emphasis

Table 4I. Baccalaureate Degrees Awarded to Underrepresented Groups

Table 4J. Baccalaureate Degrees Without Excess Credit Hours

Table 4K. Undergraduate Course Offerings

Table 4L. Faculty Teaching Undergraduates

Table 4M. Student/Faculty Ratio

Table 4N. Licensure/Certification Exam: Nursing (NCLEX)

Table 4O. Post-Graduation Metrics

\section{GRADUATE EDUCATION}

Table 5A. Graduate Degree Program Changes in AY 2013-2014

Table 5B. Graduate Degrees Awarded

Table 5C. Graduate Degrees Awarded in Areas of Strategic Emphasis

Table 5D. Licensure/Certification Exams for Graduate Programs

\section{RESEARCH \& ECONOMIC DEVELOPMENT}

Table 6A. Research and Development Expenditures

Table 6B. Centers of Excellence 
Section 1 - Financial Resources

TABLE 1A. University Education and General Revenues

\begin{tabular}{|c|c|c|c|c|c|}
\hline & $\begin{array}{r}2010-11 \\
\text { Actual }\end{array}$ & $\begin{array}{r}2011-12 \\
\text { Actual }\end{array}$ & $\begin{array}{r}2012-13 \\
\text { Actual }\end{array}$ & $\begin{array}{r}2013-14 \\
\text { Actual }\end{array}$ & $\begin{array}{r}2014-15 \\
\text { Estimates }\end{array}$ \\
\hline \multicolumn{6}{|l|}{ MAIN OPERATIONS } \\
\hline Recurring State Funds & $\$ 229,483,736$ & $\$ 179,411,103$ & $\$ 197,695,445$ & $\$ 213,139,642$ & $\$ 239,553,269$ \\
\hline Non-Recurring State Funds & $\$ 2,579,803$ & $\$ 2,073,021$ & $(\$ 42,137,455)$ & $\$ 3,190,000$ & $\$ 516,536$ \\
\hline Tuition & $\$ 109,884,700$ & $\$ 109,868,313$ & $\$ 118,200,604$ & $\$ 125,127,288$ & $\$ 131,225,502$ \\
\hline Tuition Differential Fee & $\$ 12,831,890$ & $\$ 18,917,108$ & $\$ 29,072,717$ & $\$ 28,814,565$ & $\$ 29,062,329$ \\
\hline Misc. Fees \& Fines & $\$ 3,096,769$ & $\$ 2,810,849$ & $\$ 2,568,555$ & $\$ 2,699,514$ & $\$ 3,404,085$ \\
\hline Phosphate Research TF & $\$ 7,330,654$ & $\$ 7,337,035$ & $\$ 0$ & $\$ 0$ & $\$ 0$ \\
\hline Federal Stimulus Funds & $\$ 15,169,662$ & $\$ 0$ & $\$ 0$ & $\$ 0$ & $\$ 0$ \\
\hline SUBTOTAL & $\$ 380,377,214$ & $\$ 320,417,429$ & $\$ 305,399,866$ & $\$ 372,971,009$ & $\$ 403,761,721$ \\
\hline \multicolumn{6}{|c|}{ HEALTH SCIENCE CENTER / MEDICAL SCHOOL } \\
\hline Recurring State Funds & $\$ 61,824,195$ & $\$ 63,127,971$ & $\$ 65,793,008$ & $\$ 71,529,136$ & $\$ 72,556,899$ \\
\hline Non-Recurring State Funds & $\$ 1,175,000$ & $\$ 250,000$ & $\$ 0$ & $\$ 1,409,562$ & $\$ 2,100,000$ \\
\hline Tuition & $\$ 32,942,009$ & $\$ 41,065,438$ & $\$ 48,203,644$ & $\$ 51,733,993$ & $\$ 52,165,514$ \\
\hline Tuition Differential Fee & $\$ 947,321$ & $\$ 1,703,379$ & $\$ 2,956,633$ & $\$ 3,248,580$ & $\$ 3,711,724$ \\
\hline Misc. Fees \& Fines & $\$ 1,280$ & $\$ 2,568$ & $\$ 41,978$ & $\$ 83,414$ & $\$ 87,858$ \\
\hline Phosphate Research TF & $\$ 0$ & $\$ 0$ & $\$ 0$ & $\$ 0$ & $\$ 0$ \\
\hline Federal Stimulus Funds & $\$ 4,351,772$ & $\$ 0$ & $\$ 0$ & $\$ 0$ & $\$ 0$ \\
\hline SUBTOTAL & $\$ 101,241,577$ & $\$ 106,149,356$ & $\$ 116,995,263$ & $\$ 128,004,685$ & $\$ 130,621,995$ \\
\hline
\end{tabular}

TOTAL

Recurring State Funds: State recurring funds include general revenue and lottery education \& general (E\&G) appropriations and any administered funds provided by the state, including annual adjustments of risk management insurance premiums for the estimated year. This does not include technical adjustments or transfers made by universities after the appropriation. Please note: for estimated 2013-14 this figure includes the non-recurring $\$ 300 \mathrm{M}$ system budget reduction. - Source: For actual years, SUS Final Amendment Packages; for estimated year the 2013-14 Allocation Summary and Workpapers (Total E\&G general revenue \& lottery minus non-recurring) and Board of Governors staff calculations for risk management insurance adjustments. Non-Recurring State Funds: State non-recurring funds include general revenue and lottery education \& general appropriations and any administered funds provided by the state. This does not include technical adjustments or transfers made by Universities after the appropriation - Source: non-recurring appropriations section of the annual Allocation Summary and Workpapers document and all other non-recurring budget amendments allocated later in the fiscal year. Tuition: Actual resident \& non-resident tuition revenues collected from students, net of fee waivers. - Source: Operating Budget, Report 625 - Schedule I-A. Tuition Differential Fee: Actual tuition differential revenues collected from undergraduate students - Source: Operating Budget, Report 625 - Schedule I-A. Miscellaneous Fees \& Fines: Other revenue collections include items such as application fees, late registration fees, library fines, miscellaneous revenues. This is the total revenue from Report 625 minus tuition and tuition differential fee revenues. This does not include local fees - Source: Operating Budget, Report 625 - Schedule I-A. Phosphate Research Trust Fund: State appropriation for the Florida Industrial and Phosphate Research Institute at the University of South Florida (for history years through 2012-13); beginning 2013-14 the Phosphate Research Trust Fund is appropriated through Florida Polytechnic University. Other Operating Trust Funds for UF-IFAS and UF-HSC, actual revenues from the Incidental Trust Funds and Operations \& Maintenance Trust Fund are provided by the University of Florida. Source: Final Amendment Package. Federal Stimulus Funds: Nonrecurring American Recovery and Reinvestment Act funds appropriated by the state - Source: SUS Final Amendment Package. 
Section 1 - Financial Resources (continued) TABLE 1B. University Education and General Expenditures

$\begin{array}{ccccc}2009-10 & 2010-11 & 2011-12 & 2012-13 & 2013-14 \\ \text { Actual } & \text { Actual } & \text { Actual } & \text { Actual }^{*} & \text { Actual }^{*}\end{array}$

\section{MAIN OPERATIONS}

Instruction/Research

\begin{tabular}{llllll}
\hline Administration and Support & $\$ 15,737,708$ & $\$ 18,202,340$ & $\$ 19,043,513$ & $\$ 24,357,579$ & $\$ 23,063,692$ \\
\hline PO\&M & $\$ 29,960,884$ & $\$ 29,586,468$ & $\$ 30,315,270$ & $\$ 36,507,797$ & $\$ 34,406,217$ \\
\hline Student Services & $\$ 17,871,933$ & $\$ 17,063,333$ & $\$ 14,849,300$ & $\$ 13,239,624$ & $\$ 8,281,245$ \\
\hline Library/Audio Visual & $\$ 11,694,131$ & $\$ 11,219,137$ & $\$ 10,777,212$ & $\$ 7,887,471$ & $\$ 11,495,421$ \\
\hline Other & $\$ 2,857,226$ & $\$ 2,854,224$ & $\$ 6,470,660$ & $\$ 6,957,842$ & $\$ 5,869,392$
\end{tabular}

TOTAL

$\$ 288,420,297 \quad \$ 295,421,270 \quad \$ 288,039,955$

$\$ 340,361,772 \quad \$ 335,689,057$

\section{HEALTH SCIENCE CENTER / MEDICAL SCHOOL}

\begin{tabular}{lccccc}
\hline Instruction/Research & $\$ 68,082,738$ & $\$ 76,521,544$ & $\$ 76,382,108$ & $\$ 95,673,445$ & $\$ 102,295,643$ \\
\hline Administration and Support & $\$ 5,033,768$ & $\$ 6,375,343$ & $\$ 5,076,837$ & $\$ 8,132,708$ & $\$ 6,263,326$ \\
\hline PO\&M & $\$ 84,684$ & $\$ 1,373,059$ & $\$ 1,800,847$ & $\$ 7,019,397$ & $\$ 7,391,135$ \\
\hline Library/Audio Visual & $\$ 2,473,154$ & $\$ 2,437,820$ & $\$ 3,043,160$ & $\$ 2,921,295$ & $\$ 2,587,261$ \\
\hline Teaching Hospital \& Clinics & $\$ 0$ & $\$ 0$ & $\$ 0$ & $\$ 0$ & $\$ 0$ \\
\hline Student Services, and Other & $\$ 0$ & $\$ 1,640$ & $\$ 0$ & $\$ 0$ & $\$ 0$ \\
\hline TOTAL & $\$ 75,674,344$ & $\$ 86,709,406$ & $\$ 86,302,952$ & $\$ 113,746,845$ & $\$ 118,537,365$ \\
\hline \multicolumn{1}{c}{ TOTAL } & $\$ 364,094,641$ & $\$ 382,130,676$ & $\$ 374,342,907$ & $\$ 454,108,617$ & $\$ 454,226,422$
\end{tabular}

The table reports the actual and estimated amount of expenditures from revenues appropriated by the legislature for each fiscal year. The expenditures are classified by Program Component (i.e., Instruction/Research, PO\&M, Administration, etc...) for activities directly related to instruction, research and public service. The table does not include expenditures classified as nonoperating expenditures (i.e., to service asset-related debts), and therefore excludes a small portion of the amount appropriated each year by the legislature. Note*: FY 2012-2013 reflects a change in reporting expenditures from prior years due to the new carry-forward reporting requirement as reflected in the 2013-2014 SUS Operating Budget Reports. Since these expenditures will now include carry-forward expenditures, these data are no longer comparable to the current-year revenues reported in table $1 \mathrm{~A}$, or prior year expenditures in table 1B.

Instruction \& Research: Includes expenditures for state services related to the instructional delivery system for advanced and professional education. Includes functions such as; all activities related to credit instruction that may be applied toward a postsecondary degree or certificate; non-project research and service performed to maintain professional effectives; individual or project research; academic computing support; academic source or curriculum development. Source: Operating Budget Summary - Expenditures by Program Activity (or Report 645). Administration \& Support Services: Expenditures related to the executive direction and leadership for university operations and those internal management services which assist and support the delivery of academic programs. Source: Operating Budget Summary - Expenditures by Program Activity (or Report 645). P0\&M: Plant Operations \& Maintenance expenditures related to the cleaning and maintenance of existing grounds, the providing of utility services, and the planning and design of future plant expansion and modification. Student Services: Includes resources related to physical, psychological, and social well being of the student. Includes student service administration, social and cultural development, counseling and career guidance, financial aid, and student admissions and records. Other: includes Institutes and Research Centers, Radio/TV, Museums and Galleries, Intercollegiate Athletics, Academic Infrastructure Support Organizations. Source: Operating Budget Summary - Expenditures by Program Activity (or Report 645) 


\section{Section 1 - Financial Resources (continued)}

TABLE 1C. State Funding per Full-Time Equivalent (FTE) Student

\begin{tabular}{lccccc} 
& $\begin{array}{c}\mathbf{2 0 0 9 - 1 0} \\
\text { Actual }\end{array}$ & $\begin{array}{c}\mathbf{2 0 1 0 - 1 1} \\
\text { Actual }\end{array}$ & $\begin{array}{c}\mathbf{2 0 1 1 - 1 2} \\
\text { Actual }\end{array}$ & $\begin{array}{c}\mathbf{2 0 1 2 - 1 3} \\
\text { Actual }\end{array}$ & $\begin{array}{c}\mathbf{2 0 1 3 - 1 4} \\
\text { Actual }\end{array}$ \\
\hline Appropriated Funding per FTE & & & & & \\
\hline General Revenue & $\$ 5,758$ & $\$ 5,715$ & $\$ 5,729$ & $\$ 4,332$ & $\$ 6,275$ \\
Lottery Funds & $\$ 836$ & $\$ 933$ & $\$ 994$ & $\$ 765$ & $\$ 937$ \\
Tuition \& Fees & $\$ 3,620$ & $\$ 4,156$ & $\$ 4,835$ & $\$ 5,358$ & $\$ 6,333$ \\
$\quad$ Other Trust Funds & $\$ 757$ & $\$ 474$ & $\$ 61$ & $\$ 0$ & $\$ 0$ \\
TOTAL & $\$ 10,970$ & $\$ 11,278$ & $\$ 11,619$ & $\$ 10,455$ & $\$ 13,545$ \\
Actual Funding per FTE & & & & & \\
\hline Tuition \& Fees & $\$ 3,620$ & $\$ 3,868$ & $\$ 4,407$ & $\$ 4,909$ & $\$ 5,222$ \\
TOTAL & $\$ 10,970$ & $\$ 10,990$ & $\$ 11,190$ & $\$ 10,006$ & $\$ 12,435$
\end{tabular}

Notes: (1) FTE is based on actual FTE, not funded FTE; (2) does not include Health-Science Center funds or FTE; (3) FTE for these metrics uses the standard IPEDS definition of FTE, equal to 30 credit hours for undergraduates and 24 for graduates; and (4) actual funding per student is based on actual tuition and E\&G fees (does not include local fees) collected. Sources: Appropriated totals from the annual Final Amendment Package data. Estimated year data from the Allocation Summary document. Actual Student Fees from the Operating Budget 625 reports. This does not include appropriations for special units (i.e., IFAS, Health Science Centers, and Medical Schools). Tuition and fee revenues include tuition and tuition differential fee and E\&G fees (i.e., application, late registration, and library fees/fines). Other local fees that do not support $E \& G$ activities are not included here (see Board of Governors Regulation 7.003). This data is not adjusted for inflation. 
TABLE 1D. University Other Budget Entities

2009-10

Actual
2010-11

Actual
2011-12

Actual
2012-13

Actual
2013-14

Actual

\section{Auxiliary Enterprises}

Revenues

Expenditures

REPORTED AT THE

$\$ 156,099,807 \quad \$ 164,909,208$

$\$ 169,423,868$

USF SYSTEM LEVEL

$\$ 130,615,398$

$\$ 136,370,352$

$\$ 146,226,890$

\section{Contracts \& Grants}

Revenues

Expenditures

REPORTED AT THE

USF SYSTEM LEVEL

$\$ 249,719,038$

$\$ 273,377,821$

$\$ 277,629,630$

$\$ 305,717,745 \quad \$ 305,315,644$

$\$ 318,568,385$

\section{Local Funds}

Revenues

Expenditures

REPORTED AT THE

$\$ 440,170,171 \quad \$ 442,694,125 \quad \$ 447,364,016$

USF SYSTEM LEVEL

$\$ 442,466,036 \quad \$ 447,582,389$

$\$ 451,415,960$

\section{Faculty Practice Plans}

$\begin{array}{llllll}\text { Revenues } & \$ 174,727,927 & \$ 183,622,430 & \$ 194,997,543 & \$ 199,933,005 & \$ 212,976,074 \\ \text { Expenditures } & \$ 173,643,913 & \$ 182,116,435 & \$ 196,288,464 & \$ 198,051,785 & \$ 214,268,385\end{array}$

Notes: Revenues do not include transfers. Expenditures do not include non-operating expenditures. Auxiliary Enterprises are self-supported through fees, payments and charges. Examples include housing, food services, bookstores, parking services, health centers. Contract \& Grants resources are received from federal, state or private sources for the purposes of conducting research and public service activities. Local Funds are associated with student activity (supported by the student activity fee), student financial aid, concessions, intercollegiate athletics, technology fee, green fee, and student life \& services fee. Faculty Practice Plan revenues/receipts are funds generated from faculty practice plan activities. Faculty Practice Plan expenditures include all expenditures relating to the faculty practice plans, including transfers between other funds and/or entities. This may result in double counting in information presented within the annual report. Source: Operating Budget, Report 615. 


\section{Section 1 - Financial Resources (continued)}

TABLE 1E. Voluntary Support of Higher Education

\begin{tabular}{cccccc} 
& $\mathbf{2 0 0 8 - 0 9}$ & $\mathbf{2 0 0 9 - 1 0}$ & $\mathbf{2 0 1 0 - 1 1}$ & $\mathbf{2 0 1 1 - 1 2}$ & $\mathbf{2 0 1 2 - 1 3}$ \\
\hline $\begin{array}{c}\text { Endowment Value } \\
(\$ 1000 s)\end{array}$ & $\$ 275,398$ & $\$ 295,921$ & $\$ 344,000$ & $\$ 334,100$ & $\$ 363,924$ \\
\hline $\begin{array}{c}\text { Gifts Received } \\
(\$ 1000 s)\end{array}$ & $\$ 34,011$ & $\$ 36,385$ & $\$ 81,500$ & $\$ 43,600$ & $\$ 36,520$ \\
\hline $\begin{array}{c}\text { Percentage of } \\
\text { Alumni Donors }\end{array}$ & $8.0 \%$ & $10.2 \%$ & $10.0 \%$ & $10.0 \%$ & $9.4 \%$ \\
\hline
\end{tabular}

Notes: Endowment value at the end of the fiscal year, as reported in the annual NACUBO Endowment Study. Gifts Received as reported in the Council for Aid to Education's Voluntary Support of Education (VSE) survey in the section entitled "Gift Income Summary," this is the sum of the present value of all gifts (including outright and deferred gifts) received for any purpose and from all sources during the fiscal year, excluding pledges and bequests. (There's a deferred gift calculator at www.cae.org/vse.) The present value of non-cash gifts is defined as the tax deduction to the donor as allowed by the IRS. Percentage of Alumni Donors as reported in the Council for Aid to Education's Voluntary Support of Education (VSE) survey in the section entitled "Additional Details," this is the number of alumni donors divided by the total number of alumni, as of the end of the fiscal year. "Alumni," as defined in this survey, include those holding a degree from the institution as well as those who attended the institution but did not earn a degree.

\section{TABLE 1F. Tuition Differential Fees (TDF)}

\begin{tabular}{lccc} 
& $\mathbf{2 0 1 1 - 1 2}$ & $\mathbf{2 0 1 2 - 1 3}$ & $\mathbf{2 0 1 3 - 1 4}$ \\
\hline TDF Revenues Generated & $\$ 19,548,371$ & $\$ 32,029,350$ & $\$ 32,063,146$ \\
\hline Students Receiving TDF Funded Award & 4,505 & 8,014 & 8,556 \\
Total Value of TDF Funded Financial Aid Awards & $\$ 1,302$ & $\$ 1,266$ & $\$ 1,230$
\end{tabular}

\section{Florida Student Assistance Grant (FSAG) Eligible Students}

\begin{tabular}{lccc}
\hline Number of Eligible Students & 6,936 & 11,673 & 8,777 \\
Number Receiving a TDF Waiver & 0 & 0 & 0 \\
\hline Total Value of TDF Waivers & $\$ 0$ & $\$ 0$ & $\$ 0$
\end{tabular}

Note: TDF Revenues Generated refers to actual tuition differential revenues collected from undergraduate students as reported on the Operating Budget, Report 625 - Schedule I-A. Students Receiving TDF Funded Award reports the number of unduplicated students who have received a financial aid award that was funded by tuition differential revenues. Value of TDF Funded Award refers to the average value of financial aid awards funded by the Tuition Differential Fee funds. Florida Student Assistance Grant (FSAG) Eligible Students: Number of Eligible Students refers to total annual unduplicated count of undergraduates at the institution who are eligible for FSAG in the academic year, whether or not they received FSAG awards. Number Receiving a TDF Waiver refers to annual unduplicated count of FSAG-eligible students receiving a waiver, partial or full, of the tuition differential fees at the institution during the academic year, regardless of the reason for the waiver. Value of TDF Waivers refers to the average value of waivers provided to FSAG-eligible undergraduates at the institution during the academic year, regardless of the reason for the waiver. 


\section{Section 2 - Personnel}

\section{TABLE 2A. Personnel Headcount (in Fall term only)}

\begin{tabular}{|c|c|c|c|c|c|}
\hline & 2009 & 2010 & 2011 & 2012 & 2013 \\
\hline \multicolumn{6}{|l|}{ Full-time Employees } \\
\hline Tenured Faculty & 683 & 691 & 684 & 661 & 715 \\
\hline Tenure-track Faculty & 297 & 309 & 338 & 329 & 293 \\
\hline Non-Tenure Track Faculty & 444 & 466 & 457 & 469 & 842 \\
\hline Instructors Without Faculty Status & 0 & 0 & 0 & 0 & 0 \\
\hline Graduate Assistants/Associates & 0 & 0 & 0 & 0 & 0 \\
\hline Non-Instructional Employees & 3,740 & 3,915 & 4,100 & 3,964 & 4,799 \\
\hline FULL-TIME SUBTOTAL & 5,164 & 5,381 & 5,579 & 5,423 & 6,649 \\
\hline \multicolumn{6}{|l|}{ Part-time Employees } \\
\hline Tenured Faculty & 57 & 53 & 45 & 55 & 25 \\
\hline Tenure-track Faculty & 21 & 25 & 19 & 19 & 13 \\
\hline Non-Tenure Track Faculty & 132 & 137 & 190 & 526 & 572 \\
\hline Instructors Without Faculty Status & 0 & 3 & 0 & 0 & 0 \\
\hline Graduate Assistants/Associates & 1,835 & 2,033 & 2,026 & 1,988 & 2,055 \\
\hline Non-Instructional Employees & 156 & 143 & 209 & 778 & 81 \\
\hline PART-TIME SUBTOTAL & 2,201 & 2,392 & 2,489 & 3,366 & 2,746 \\
\hline TOTAL & 7,365 & 7,773 & 8,068 & 8,789 & 9,395 \\
\hline
\end{tabular}

Note: This table is based on the annual IPEDS Human Resources Survey, and provides full- and part-time medical and non-medical staff by faculty status and primary function/occupational activity. Tenured and Tenure-Track Faculty include those categorized within instruction, research, or public service. Non-Tenure Track Faculty includes adjunct faculty (on annual and less than annual contracts) and faculty on multi-year contracts categorized within instruction, research, or public service. Instructors Without Faculty Status includes postdoctoral research associates, and individuals hired as a staff member primarily to do research on a 3-year contract without tenure eligibility categorized within instruction, research, or public service. Non-Instructional Employees includes all executive, administrative and managerial positions regardless of faculty status; as well as, other support and service positions regardless of faculty status. Note: The universities vary on how they classify adjuncts (some include them as non-tenure track faculty while others do not consider them faculty and report them as instructors without faculty status) and part-time non-instructional employees. 


\section{Section 3 - Enrollment}

TABLE 3A. Headcount Enrollment by Student Type and Level

\begin{tabular}{lccccc} 
& Fall 2009 & Fall 2010 & Fall 2011 & Fall 2012 & Fall 2013 \\
\hline TOTAL & 41,532 & 41,846 & 41,036 & 41,212 & 41,688
\end{tabular}

\section{UNDERGRADUATE}

\begin{tabular}{lccccc}
\hline FTIC (Regular Admit) & 15,632 & 16,239 & 15,550 & 15,231 & 15,330 \\
FTIC (Profile Admit) & 276 & 218 & 181 & 157 & 143 \\
AA Transfers & 7,473 & 8,149 & 8,489 & 8,651 & 8,615 \\
Other Transfers & 7,681 & 6,719 & 6,145 & 6,393 & 6,302 \\
\hline Subtotal & $\mathbf{3 1 , 0 6 2}$ & $\mathbf{3 1 , 3 2 5}$ & $\mathbf{3 0 , 3 6 5}$ & $\mathbf{3 0 , 4 3 2}$ & $\mathbf{3 0 , 3 9 0}$
\end{tabular}

GRADUATE

\begin{tabular}{lccccc}
\hline Master's & 5,945 & 5,935 & 5,843 & 5,884 & 6,126 \\
Research Doctoral & 2,180 & 2,289 & 2,362 & 2,336 & 2,294 \\
Professional Doctoral & 595 & 604 & 676 & 905 & 1,220 \\
Dentistry & 0 & 0 & 0 & 0 & 0 \\
Law & 0 & 0 & 0 & 0 & 0 \\
Medicine & 482 & 473 & 502 & 549 & 620 \\
Nursing Practice & 0 & 32 & 27 & 30 & 43 \\
Pharmacy & 0 & 0 & 53 & 119 & 225 \\
Physical Therapist & 74 & 99 & 94 & 207 & 332 \\
Veterinary Medicine & 0 & 0 & 0 & 0 & 0 \\
Other & 0 & 0 & 0 & 0 & 0 \\
\hline Subtotal & $\mathbf{8 , 6 8 1}$ & $\mathbf{8 , 8 2 8}$ & $\mathbf{8 , 8 8 1}$ & $\mathbf{9 , 1 2 5}$ & $\mathbf{9 , 6 4 0}$ \\
UNCLASSIFIED & & & & & \\
\hline
\end{tabular}

Note: This table reports the number of students enrolled at the university by student type categories. The determination for undergraduate, graduate and unclassified is based on the institutional class level values. Unclassified refers to a student who has not yet been formally admitted into a degree program but is enrolled. The student type for undergraduates is based on the Type of Student at Time of Most Recent Admission. The student type for graduates is based on the degree that is sought and the student CIP code. 


\section{Section 3 - Enrollment (continued)}

TABLE 3B. Full-Time Equivalent (FTE) Enrollment [State Fundable only]

2011-12 2012-13

2013-14

StateFunded

Actual

State-

FLORIDA RESIDENTS

\begin{tabular}{lcc|cc|cc}
\hline Lower-Division & 8,617 & 8,129 & 8,617 & 7,837 & 8,617 & 7,685 \\
Upper-Division & 10,493 & 11,964 & 10,493 & 11,997 & 10,493 & 11,679 \\
Master's (GRAD I) & 2,775 & 3,139 & 2,775 & 3,082 & 2,775 & 3,050 \\
Doctoral (GRAD II) & 623 & 974 & 623 & 962 & 623 & 945 \\
\hline Subtotal & $\mathbf{2 2 , 5 0 8}$ & $\mathbf{2 4 , 2 0 6}$ & $\mathbf{2 2 , 5 0 8}$ & $\mathbf{2 3 , 8 7 8}$ & $\mathbf{2 2 , 5 0 8}$ & $\mathbf{2 3 , 3 5 9}$
\end{tabular}

NON-FLORIDA RESIDENTS

\begin{tabular}{lcc|cc|cc}
\hline Lower-Division &. & 468 &. & 589 &. & 718 \\
Upper-Division &. & 447 &. & 531 &. & 649 \\
Master's (GRAD I) &. & 529 &. & 625 &. & 785 \\
Doctoral (GRAD II) &. & 579 &. & 632 &. & 639 \\
\hline Subtotal & $\mathbf{1 , 3 0 2}$ & $\mathbf{2 , 0 2 3}$ & $\mathbf{1 , 3 0 2}$ & $\mathbf{2 , 3 7 7}$ & $\mathbf{1 , 3 0 2}$ & $\mathbf{2 , 7 9 1}$
\end{tabular}

TOTAL FTE

\begin{tabular}{lcc|cc|cc}
\hline Lower-Division & $\cdot$ & 8,597 & $\cdot$ & 8,426 &. & 8,403 \\
Upper-Division & $\cdot$ & 12,411 & $\cdot$ & 12,528 & $\cdot$ & 12,329 \\
Master's (GRAD I) & $\cdot$ & 3,669 & $\cdot$ & 3,707 & $\cdot$ & 3,835 \\
Doctoral (GRAD II) & $\cdot$ & 1,553 & $\cdot$ & 1,594 &. & 1,583 \\
\hline Total & $\mathbf{2 3 , 8 1 0}$ & $\mathbf{2 6 , 2 3 0}$ & $\mathbf{2 3 , 8 1 0}$ & $\mathbf{2 6 , 2 5 5}$ & $\mathbf{2 3 , 8 1 0}$ & $\mathbf{2 6 , 1 5 0}$ \\
\hline Total (US Definition) & $\mathbf{3 1 , 7 4 7}$ & $\mathbf{3 4 , 9 7 3}$ & $\mathbf{3 1 , 7 4 7}$ & $\mathbf{3 5 , 0 0 7}$ & $\mathbf{3 1 , 7 4 7}$ & $\mathbf{3 4 , 8 6 6}$ \\
\hline
\end{tabular}

Notes: Full-time Equivalent (FTE) student is a measure of instructional effort (and student activity) that is based on the number of credit hours that students enroll by course level. FTE is based on the Florida definition, which divides undergraduate credit hours by 40 and graduate credit hours by 32 (US definition based on Undergraduate FTE $=30$ and Graduate FTE $=24$ credit hours). Funded enrollment as reported in the General Appropriations Act and set by the legislature. Actual enrollment only reports 'state-fundable' FTE as reported by Universities to the Board of Governors in the Student Instruction File (SIF). Totals are actual and may not equal sum of reported student levels due to rounding of student level FTE. Total FTE are equal in tables $3 \mathrm{~B}$ and $3 \mathrm{C}$. 


\section{Section 3 - Enrollment (continued)}

TABLE 3C. Full-Time Equivalent (FTE) Enrollment by Method of Instruction

\begin{tabular}{lrrrr} 
& $\mathbf{2 0 1 0 - 1 1}$ & $\mathbf{2 0 1 1 - 1 2}$ & $\mathbf{2 0 1 2 - 1 3}$ & $\mathbf{2 0 1 3 - 1 4}$ \\
\hline TRADITIONAL & \multicolumn{3}{c}{} & \\
\hline Lower-Division & 7,497 & 7,217 & 7,127 & 7,200 \\
Upper-Division & 9,220 & 9,365 & 9,168 & 8,867 \\
Master's (GRAD 1) & 2,543 & 2,600 & 2,551 & 2,718 \\
Doctoral (GRAD 2) & 1,452 & 1,490 & 1,520 & 1,494 \\
Total & $\mathbf{2 0 , 7 1 2}$ & $\mathbf{2 0 , 6 7 2}$ & $\mathbf{2 0 , 3 6 6}$ & $\mathbf{2 0 , 2 7 8}$
\end{tabular}

\section{HYBRID}

$\begin{array}{lrrrr}\text { Lower-Division } & 22 & 42 & 83 & 57 \\ \text { Upper-Division } & 289 & 302 & 344 & 270 \\ \text { Master's (GRAD 1) } & 97 & 141 & 136 & 151 \\ \text { Doctoral (GRAD 2) } & 9 & 5 & 8 & 10 \\ \text { Total } & 417 & 490 & 571 & 487\end{array}$

\section{DISTANCE LEARNING}

$\begin{array}{lrrrr}\text { Lower-Division } & 1,292 & 1,338 & 1,216 & 1,147 \\ \text { Upper-Division } & 2,075 & 2,743 & 3,016 & 3,192 \\ \text { Master's (GRAD 1) } & 1,010 & 928 & 1,020 & 966 \\ \text { Doctoral (GRAD 2) } & 48 & 61 & 67 & 81 \\ \text { Total } & \mathbf{4 , 4 2 5} & \mathbf{5 , 0 7 0} & \mathbf{5 , 3 1 9} & \mathbf{5 , 3 8 6}\end{array}$

\section{TOTAL}

$\begin{array}{lrrrr}\text { Lower-Division } & 8,811 & 8,597 & 8,426 & 8,403 \\ \text { Upper-Division } & 11,584 & 12,410 & 12,528 & 12,328 \\ \text { Master's (GRAD 1) } & 3,650 & 3,669 & 3,707 & 3,835 \\ \text { Doctoral (GRAD 2) } & 1,509 & 1,556 & 1,594 & 1,584 \\ \text { Total } & \mathbf{2 5 , 5 5 4} & \mathbf{2 6 , 2 3 2} & \mathbf{2 6 , 2 5 5} & \mathbf{2 6 , 1 5 1}\end{array}$

Note: Full-time Equivalent (FTE) student is a measure of instructional effort (and student activity) that is based on the number of credit hours that students enroll by course level. FTE is based on the Florida definition, which divides undergraduate credit hours by 40 and graduate credit hours by 32. Distance Learning is a course in which at least 80 percent of the direct instruction of the course is delivered using some form of technology when the student and instructor are separated by time or space, or both (per 1009.24(17), F.S.). Hybrid is a course where 50\% to $79 \%$ of the instruction is delivered using some form of technology, when the student and instructor are separated by time or space, or both (per SUDS data element 2052). Traditional (and Technology Enhanced) refers to primarily face to face instruction utilizing some form of technology for delivery of supplemental course materials for no more than $49 \%$ of instruction (per SUDS data element 2052). Totals are actual and may not equal sum of reported student levels due to rounding of student level FTE. Total FTE are equal in tables 3B and 3C. 


\section{Section 3 - Enrollment (continued)}

TABLE 3D. Headcount Enrollment by Military Status and Student Level

\begin{tabular}{lcccc} 
& Fall 2010 & Fall 2011 & Fall 2012 & Fall 2013 \\
\hline MILITARY & & & & \\
\hline Unclassified & 26 & 32 & 25 & 26 \\
Undergraduate & 699 & 773 & 827 & 830 \\
Master's (GRAD 1) & 137 & 138 & 154 & 166 \\
Doctoral (GRAD 2) & 18 & 26 & 27 & 18 \\
Total & $\mathbf{8 8 0}$ & $\mathbf{9 6 9}$ & $\mathbf{1 , 0 3 3}$ & $\mathbf{1 , 0 4 0}$
\end{tabular}

\section{ELIGIBLE DEPENDENT}

$\begin{array}{lcccc}\text { Unclassified } & 3 & 1 & 5 & 0 \\ \text { Undergraduate } & 145 & 147 & 153 & 165 \\ \text { Master's (GRAD 1) } & 11 & 13 & 13 & 16 \\ \text { Doctoral (GRAD 2) } & 0 & 0 & 1 & 1 \\ \text { Total } & 159 & 161 & 172 & 182\end{array}$

NON-MILITARY

$\begin{array}{lcccc}\text { Unclassified } & 1,664 & 1,756 & 1,625 & 1,631 \\ \text { Undergraduate } & 30,481 & 29,446 & 29,452 & 29,396 \\ \text { Master's (GRAD 1) } & 6,231 & 6,219 & 6,366 & 6,779 \\ \text { Doctoral (GRAD 2) } & 2,431 & 2,485 & 2,564 & 2,660 \\ \text { Total } & \mathbf{4 0 , 8 0 7} & \mathbf{3 9 , 9 0 6} & \mathbf{4 0 , 0 0 7} & \mathbf{4 0 , 4 6 6}\end{array}$

Note: This table provides trend data on the number of students enrolled based on their military status. Military includes students who were classified as Active Duty, Veterans, National Guard, or Reservist.. Eligible Dependents includes students who were classified as eligible dependents (dependents who received veteran's benefits). Non-Military includes all other students.

\section{TABLE 3E. University Access Rate: Undergraduate Enrollment with Pell Grant}

\begin{tabular}{lccccc} 
& Fall 2009 & Fall 2010 & Fall 2011 & Fall 2012 & Fall 2013 \\
\hline Pell Grant Recipients & 10,169 & 12,118 & 12,607 & 12,606 & 12,498 \\
\hline Percent with Pell Grant & $33 \%$ & $39 \%$ & $42 \%$ & $42 \%$ & $42 \%$
\end{tabular}

Note: This table reports the University's Access Rate, which is a measure of the percentage of undergraduate students who have received a federal Pell grant award during a given Fall term. The top row reports the number of students who received a Pell Grant award. The bottom row provides the percentage of eligible students that received a Pell Grant award. This metric was included in the Board of Governors Performance Based Funding Model in 2014 - for more information see: http://www.flbog.edu/about/budget/performance funding.php. 


\section{Section 4 - Undergraduate Education} TABLE 4A. Baccalaureate Degree Program Changes in AY 2013-14

\begin{tabular}{|c|c|c|c|c|c|}
\hline Title of Program & $\begin{array}{c}\text { Six-digit } \\
\text { CIP } \\
\text { Code }\end{array}$ & $\begin{array}{l}\text { Degree } \\
\text { Level }\end{array}$ & $\begin{array}{l}\text { Date of } \\
\text { UBOT } \\
\text { Action }\end{array}$ & $\begin{array}{c}\text { Starting } \\
\text { or Ending } \\
\text { Term }\end{array}$ & Comments \\
\hline \multicolumn{6}{|l|}{ New Programs } \\
\hline \multicolumn{6}{|l|}{$\mathrm{N} / \mathrm{A}$} \\
\hline \multicolumn{6}{|l|}{ Terminated Programs } \\
\hline Interdisciplinary Studies & 30.9999 & Bachelors & $3 / 6 / 2014$ & 2014 Summer & \\
\hline Business Managerial Economics & 52.0601 & Bachelors & $3 / 6 / 2014$ & 2014 Summer & \\
\hline Social Science, General (Lakeland) & 45.0101 & Bachelors & $6 / 6 / 2013$ & 2013 Summer & \\
\hline Psychology, General (Lakeland) & 42.0101 & Bachelors & $6 / 6 / 2013$ & 2013 Summer & \\
\hline Marketing Management (Lakeland) & 52.1401 & Bachelors & $6 / 6 / 2013$ & 2013 Summer & \\
\hline Information Technology (Lakeland) & 11.0103 & Bachelors & $6 / 6 / 2013$ & 2013 Summer & \\
\hline Industrial Engineering (Lakeland) & 14.3501 & Bachelors & 6/6/2013 & 2013 Summer & \\
\hline $\begin{array}{l}\text { Elementary Education and Teaching } \\
\text { (Lakeland) }\end{array}$ & 13.1202 & Bachelors & $6 / 6 / 2013$ & 2013 Summer & \\
\hline Criminology (Lakeland) & 45.0401 & Bachelors & 6/6/2013 & 2013 Summer & \\
\hline $\begin{array}{l}\text { Business Administration and } \\
\text { Management, General (Lakeland) }\end{array}$ & 52.0201 & Bachelors & $6 / 6 / 2013$ & 2013 Summer & \\
\hline Applied Science (Lakeland) & 24.0102 & Bachelors & $6 / 6 / 2013$ & 2013 Summer & \\
\hline Business, General (Lakeland) & 52.0101 & Bachelors & $6 / 6 / 2013$ & 2013 Summer & \\
\hline \multicolumn{6}{|c|}{ Programs Suspended for New Enrollments } \\
\hline Information Science/Studies & 11.0401 & Bachelors & - & 2010 Fall & \\
\hline
\end{tabular}

N/A

Note: This table does not include new majors or concentrations added under an existing degree program CIP Code. This table reports the new and terminated program changes based on Board action dates between May 5, 2013 and May 4, 2014.

New Programs are proposed new degree programs that have been completely through the approval process at the university and, if appropriate, the Board of Governors. Does not include new majors or concentrations added under an existing degree program CIP Code.

Terminated Programs are degree programs for which the entire CIP Code has been terminated and removed from the university's inventory of degree programs. Does not include majors or concentrations terminated under an existing degree program CIP Code if the code is to remain active on the academic degree inventory.

Inactive Programs are degree programs for which enrollments have been temporarily suspended for the entire CIP Code, but the program CIP Code has not been terminated. Does not include majors or concentrations suspended under an existing degree program CIP Code if the code is to remain active on the academic degree inventory and new enrollments in any active major will be reported.

New Programs Considered by University But Not Approved includes any programs considered by the university board of trustees, or any committee of the board, but not approved for implementation. Also include any programs that were returned prior to board consideration by the university administration for additional development, significant revisions, or re-conceptualization; regardless of whether the proposal was eventually taken to the university board for approval. Count the returns once per program, not multiple times the proposal was returned for revisions, unless there is a total re-conceptualization that brings forward a substantially different program in a different CIP Code. 


\section{Section 4 - Undergraduate Education (continued)}

\section{TABLE 4B. Full-time, First-Time-in-College (FTIC) Retention Rates} Retained in the Second Fall Term at Same University

\begin{tabular}{cccccc} 
& $\mathbf{2 0 0 9 - 1 0}$ & $\mathbf{2 0 1 0 - 1 1}$ & $\mathbf{2 0 1 1 - 1 2}$ & $\mathbf{2 0 1 2 - 1 3}$ & $\begin{array}{c}\mathbf{2 0 1 3 - 1 4} \\
\text { Preliminary }\end{array}$ \\
\hline Cohort Size & 3,814 & 4,477 & 3,451 & 3,825 & 3,860 \\
\hline \% Retained Same University & $88 \%$ & $86 \%$ & $87 \%$ & $89 \%$ & $89 \%$ \\
\hline \% Retained Other USF Institution & $88 \%$ & $86 \%$ & $87 \%$ & $89 \%$ & $89 \%$ \\
\hline $\begin{array}{c}\text { \% Retained Same University } \\
\text { with GPA of 2.0 or higher }\end{array}$ & $84 \%$ & $82 \%$ & $85 \%$ & $86 \%$ & $87 \%$ \\
\hline $\begin{array}{c}\text { \% Retained Other USF Institution } \\
\text { with GPA of 2.0 or higher }\end{array}$ & $84 \%$ & $82 \%$ & $85 \%$ & $87 \%$ & $87 \%$
\end{tabular}

Notes: Cohorts are based on undergraduate students who enter the institution in the Fall term (or Summer term and continue into the Fall term). Percent Retained is based on student enrollment in the Fall term following their first year. Percent Retained with GPA Above 2.0 is based on student enrollment in the Fall term following their first years for those students with a GPA of 2.0 or higher at the end of their first year (Fall, Spring, Summer). The most recent year of Retention data is based on preliminary data (SIFP file) that is comparable to the final data (SIF file) but may be revised in the following years based on changes in student cohorts. Note: The historical retention rates with GPAs of 2 or higher have been revised since the 2012-13 Accountability report to fix an error that impacted every institutions rates.

\section{TABLE 4C. Full-time, First-Time-in-College (FTIC) Six-Year Graduation Rates}

\begin{tabular}{cccccc} 
Term of Entry & $\mathbf{2 0 0 4 - 1 0}$ & $\mathbf{2 0 0 5 - 1 1}$ & $\mathbf{2 0 0 6 - 1 2}$ & $\mathbf{2 0 0 7 - 1 3}$ & $\begin{array}{c}\mathbf{2 0 0 8 - 1 4} \\
\text { Preliminary }\end{array}$ \\
\hline Cohort Size & 3,979 & 3,926 & 4,000 & 3,755 & 4,015 \\
\hline$\%$ Graduated & $52 \%$ & $52 \%$ & $57 \%$ & $63 \%$ & $66 \%$ \\
\hline \% Still Enrolled & $9 \%$ & $9 \%$ & $8 \%$ & $6 \%$ & $5 \%$ \\
\hline \% Success Rate & $61 \%$ & $60 \%$ & $65 \%$ & $70 \%$ & $72 \%$
\end{tabular}

Notes: Cohorts are based on undergraduate students who enter the institution in the Fall term (or Summer term and continue into the Fall term). Percent Graduated is based on federal rate and does not include students who originally enroll as part-time students, or who transfer into the institution. This metric complies with the requirements of the federal Student Right to Know Act that requires institutions to report the completion status at $150 \%$ of normal time (or six years). Success Rate measures the percentage of an initial cohort of students who have either graduated or are still enrolled at the same university. Since degrees can be awarded after the last semester of coursework, the most recent year of data in this table provides preliminary data that may change with the addition of "late degrees". Late degrees reported in conjunction with the IPEDS Graduation Rate Survey due in mid-April will be reflected in the following year. 


\section{Section 4 - Undergraduate Education (continued)}

TABLE 4D. FTIC Graduation Rates (includes Full- and Part-time students)

\begin{tabular}{lccccc}
$\mathbf{4 - \text { Year Rates }}$ & $\mathbf{2 0 0 6 - 1 0}$ & $\mathbf{2 0 0 7 - 1 1}$ & $\mathbf{2 0 0 8 - 1 2}$ & $\mathbf{2 0 0 9 - 1 3}$ & $\begin{array}{c}\mathbf{2 0 1 0 - 1 4} \\
\text { Preliminary }\end{array}$ \\
\hline Cohort Size & 4,180 & 3,936 & 4,086 & 3,851 & 4,512 \\
Same University & $28 \%$ & $35 \%$ & $38 \%$ & $42 \%$ & $44 \%$ \\
\hline Other USF Institution & $0.4 \%$ & $0.1 \%$ & $0.3 \%$ & $0.2 \%$ & $0.3 \%$ \\
\hline Other SUS University & $1 \%$ & $1 \%$ & $1 \%$ & $1 \%$ & $2 \%$ \\
\hline TOTAL & $30 \%$ & $36 \%$ & $39 \%$ & $44 \%$ & $46 \%$
\end{tabular}

\begin{tabular}{lccccc}
$\mathbf{6}-$ Year Rates & $\mathbf{2 0 0 4 - 1 0}$ & $\mathbf{2 0 0 5 - 1 1}$ & $\mathbf{2 0 0 6 - 1 2}$ & $\mathbf{2 0 0 7 - 1 3}$ & $\begin{array}{c}\mathbf{2 0 0 8 - 1 4} \\
\text { Preliminary }\end{array}$ \\
\hline Cohort Size & 4,492 & 4,231 & 4,180 & 3,936 & 4,086 \\
Same University & $51 \%$ & $51 \%$ & $56 \%$ & $63 \%$ & $66 \%$ \\
\hline Other USF Institution & $1 \%$ & $1 \%$ & $1 \%$ & $1 \%$ & $1 \%$ \\
\hline Other SUS University & $5 \%$ & $4 \%$ & $4 \%$ & $3 \%$ & $4 \%$ \\
\hline TOTAL & $57 \%$ & $56 \%$ & $61 \%$ & $67 \%$ & $70 \%$
\end{tabular}

Notes: (1) Cohorts are based on undergraduate students who enter the institution in the Fall term (or Summer term and continue into the Fall term). Firsttime-in-college (FTIC) cohort is defined as undergraduates entering in fall term (or summer continuing to fall) with fewer than 12 hours earned after high school graduation. Students of degree programs longer than four years (eg, PharmD) are included in the cohorts. The initial cohorts can be revised to remove students, who have allowable exclusions as defined by IPEDS, from the cohort. (2) Graduates are students in the cohort who have graduated by the summer term in their fourth or sixth year. Degree data often includes 'late degrees' which are degrees that were awarded in a previous term, but reported to SUDS later; so, the most recent year of data in this table only provides preliminary graduation rate data that may change with the addition of "late degrees". Late degrees reported in conjunction with the IPEDS Graduation Rate Survey due in mid-February will be reflected in the following year. Same University provides data for students in the cohort who graduated from the same institution. Other SUS University provides data for students in the cohort who graduated from a different SUS institution. Outside the SUS provides data for students in the cohort who did not graduate from the SUS, but did graduate from another institution outside the State University System. 


\section{Section 4 - Undergraduate Education (continued)}

TABLE 4E. AA Transfer Graduation Rates

\begin{tabular}{|c|c|c|c|c|c|}
\hline 2 - Year Rates & $2008-10$ & $2009-11$ & $2010-12$ & 2011-13 & $\begin{array}{c}\text { 2012-14 } \\
\text { Preliminary }\end{array}$ \\
\hline Cohort Size & 1,969 & 1,815 & 1,932 & 2,009 & 1,942 \\
\hline Same University & $26 \%$ & $28 \%$ & $28 \%$ & $27 \%$ & $30 \%$ \\
\hline Other SUS University & $1 \%$ & $0 \%$ & $0 \%$ & $0 \%$ & $1 \%$ \\
\hline State University System & $26 \%$ & $29 \%$ & $29 \%$ & $28 \%$ & $30 \%$ \\
\hline 4 - Year Rates & $2006-10$ & $2007-11$ & 2008-12 & $2009-13$ & $\begin{array}{c}\text { 2010-14 } \\
\text { Preliminary }\end{array}$ \\
\hline Cohort Size & 1,538 & 1,711 & 1,969 & 1,815 & 1,932 \\
\hline Same University & $62 \%$ & $62 \%$ & $65 \%$ & $68 \%$ & $66 \%$ \\
\hline Other SUS University & $3 \%$ & $3 \%$ & $2 \%$ & $3 \%$ & $2 \%$ \\
\hline State University System & $64 \%$ & $65 \%$ & $67 \%$ & $71 \%$ & $68 \%$ \\
\hline
\end{tabular}

Notes: AA Transfer cohort is defined as undergraduates entering in the fall term (or summer continuing to fall) and having earned an AA degree from an institution in the Florida College System. (1) Cohorts are based on undergraduate students who enter the institution in the Fall term (or Summer term and continue into the Fall term); (2) Success Rate measures the percentage of an initial cohort of students who have either graduated or are still enrolled; (3) since degrees can be awarded after the last semester of coursework, the most recent year of data in this table provides preliminary graduation rate data that may change with the addition of "late degrees". Late degrees reported in conjunction with the IPEDS Graduation Rate Survey due in mid-April will be reflected in the following year.

\section{TABLE 4F. Other Transfer Graduation Rates}

\begin{tabular}{cccccc}
$\mathbf{5 - Y e a r ~ R a t e s ~}$ & $\mathbf{2 0 0 4 - 0 9}$ & $\mathbf{2 0 0 5 - 1 0}$ & $\mathbf{2 0 0 6 - 1 1}$ & $\mathbf{2 0 0 7 - 1 2}$ & $\begin{array}{c}\mathbf{2 0 0 8 - 1 3} \\
\text { Preliminary }\end{array}$ \\
\hline Cohort Size & 2,138 & 2,139 & 2,364 & 1,877 & 2,181 \\
Same University & $52 \%$ & $58 \%$ & $57 \%$ & $64 \%$ & $63 \%$ \\
\hline Other SUS University & $3 \%$ & $4 \%$ & $3 \%$ & $2 \%$ & $2 \%$ \\
\hline State University System & $55 \%$ & $62 \%$ & $61 \%$ & $66 \%$ & $65 \%$
\end{tabular}

Notes: (1) Cohorts are based on undergraduate students who enter the institution in the Fall term (or Summer term and continue into the Fall term); (2) Success Rate measures the percentage of an initial cohort of students who have either graduated or are still enrolled; (3) since degrees can be awarded after the last semester of coursework, the most recent year of data in this table provides preliminary graduation rate data that may change with the addition of "late degrees". Late degrees reported in conjunction with the IPEDS Graduation Rate Survey due in mid-April will be reflected in the following year. 


\section{Section 4 - Undergraduate Education (continued)} TABLE 4G. Baccalaureate Degrees Awarded

\begin{tabular}{lccccc} 
& $\mathbf{2 0 0 9 - 1 0}$ & $\mathbf{2 0 1 0 - 1 1}$ & $\mathbf{2 0 1 1 - 1 2}$ & $\mathbf{2 0 1 2 - 1 3}$ & $\mathbf{2 0 1 3 - 1 4}$ \\
\hline TOTAL (First Majors) & 6,852 & 7,050 & 7,607 & 7,617 & 8,079 \\
TOTAL (Second Majors) & 120 & 127 & 173 & 173 & 186
\end{tabular}

Note: This table reports the number of degrees awarded by academic year. First Majors include the most common scenario of one student earning one degree in one Classification of Instructional Programs (CIP) code. In those cases where a student earns a baccalaureate degree under two different degree CIPs, a distinction is made between "dual degrees" and "dual majors." Also included in first majors are "dual degrees" which are counted as separate degrees (i.e., counted twice). In these cases, both degree CIPs receive a "degree fraction" of 1.0. Second Majors include all dual/second majors (i.e., degree CIP receive a degree fraction that is less than 1). The calculation of degree fractions is made according to each institution's criteria. The calculation for the number of second majors rounds each degree CIP's fraction of a degree up to 1 and then sums the total. Second Majors are typically used when providing degree information by discipline/CIP, to better conveys the number of graduates who have specific skill sets associated with each discipline. Note: USF and BOG data have slight differences in the number of degrees awarded - the data presented above are from the State University Database System (SUDS).

\section{TABLE 4H. Baccalaureate Degrees in Programs of Strategic Emphasis (PSE)}

[Includes Second Majors]

\begin{tabular}{lccccc} 
& $\mathbf{2 0 0 9 - 1 0}$ & $\mathbf{2 0 1 0 - 1 1}$ & $\mathbf{2 0 1 1 - 1 2}$ & $\mathbf{2 0 1 2 - 1 3}$ & $\mathbf{2 0 1 3 - 1 4}$ \\
\hline STEM & 1,493 & 1,572 & 1,844 & 1,987 & 1,975 \\
\hline HEALTH & 440 & 446 & 695 & 818 & 1,099 \\
\hline GLOBALIZATION & 229 & 243 & 284 & 249 & 284 \\
\hline EDUCATION & 623 & 596 & 570 & 481 & 516 \\
\hline GAP ANALYSIS & 546 & 547 & 513 & 495 & 549 \\
\hline SUBTOTAL & $\mathbf{3 , 3 3 1}$ & $\mathbf{3 , 4 0 4}$ & $\mathbf{3 , 9 0 6}$ & $\mathbf{4 , 0 3 0}$ & $\mathbf{4 , 4 2 3}$ \\
\hline PSE PERCENT OF TOTAL & $\mathbf{4 8 \%}$ & $\mathbf{4 7 \%}$ & $\mathbf{5 0 \%}$ & $\mathbf{5 2 \%}$ & $\mathbf{5 4 \%}$
\end{tabular}

Notes: This is a count of baccalaureate majors for specific Programs of Strategic Emphasis, as determined by the Board of Governors staff with consultation with business and industry groups and input from universities. A student who has multiple majors in the subset of targeted Classification of Instruction Program codes will be counted twice (i.e., double-majors are included). 


\section{Section 4 - Undergraduate Education (continued)}

\section{TABLE 4I. Baccalaureate Degrees Awarded to Underrepresented Groups}

\section{9-10 2010-11 2011-12 2012-13 2013-14}

\section{Non-Hispanic Black}

$\begin{array}{lccccc}\text { Number of Degrees } & 824 & 875 & 856 & 884 & 888 \\ \text { Percentage of Degrees } & 12 \% & 13 \% & 12 \% & 12 \% & 11 \%\end{array}$

\section{Hispanic}

\begin{tabular}{lccccc} 
Number of Degrees & 863 & 1,033 & 1,268 & 1,285 & 1,493 \\
Percentage of Degrees & $13 \%$ & $15 \%$ & $17 \%$ & $17 \%$ & $19 \%$ \\
ell-Grant Recipients & & & & & \\
\hline Number of Degrees & 2,806 & 3,130 & 3,859 & 4,038 & 4,397 \\
Percentage of Degrees & $42 \%$ & $46 \%$ & $50 \%$ & $54 \%$ & $56 \%$
\end{tabular}

Note: Non-Hispanic Black and Hispanic do not include students classified as Non-Resident Alien or students with a missing race code. Students who earn two distinct degrees in the same term are counted twice - whether their degrees are from the same six-digit CIP code or different CIP codes. Students who earn only one degree are counted once - even if they completed multiple majors or tracks. Percentage of Degrees is based on the number of baccalaureate degrees awarded to non-Hispanic Black and Hispanic students divided by the total degrees awarded - excluding those awarded to non-resident aliens and unreported.

Pell-Grant recipients are defined as those students who have received a Pell grant from any SUS Institution within six years of graduation - excluding those awarded to non-resident aliens, who are only eligible for Pell grants in special circumstances. Percentage of Degrees is based on the number of baccalaureate degrees awarded to Pell recipients, as shown above, divided by the total degrees awarded - excluding those awarded to non-resident aliens. Notes on Trends: In 2007, the US Department of Education re-classified the taxonomy for self-reported race/ethnicity categories and allowed universities a two-year phase-in process before all institutions were required to report based on the new categories for the 2011-12 academic year. This reclassification will impact trends. 


\section{Section 4 - Undergraduate Education (continued)} TABLE 4J. Baccalaureate Degrees Without Excess Credit Hours

\begin{tabular}{|c|c|c|c|c|}
\hline & $2009-10$ & 2011-12 & 2012-13* & 2013-14 \\
\hline FTIC & \multirow{4}{*}{$\begin{array}{l}\text { Data not parsed by } \\
\text { USF System Institution }\end{array}$} & $56 \%$ & $57 \%$ & $63 \%$ \\
\hline AA Transfers & & $58 \%$ & $69 \%$ & $72 \%$ \\
\hline Other Transfers & & $39 \%$ & $53 \%$ & $59 \%$ \\
\hline TOTAL & & $52 \%$ & $60 \%$ & $65 \%$ \\
\hline
\end{tabular}

Notes: This table is based on statute 1009.286 (see link), and excludes certain types of student credits (ie, accelerated mechanisms, remedial coursework, non-native credit hours that are not used toward the degree, non-native credit hours from failed, incomplete, withdrawn, or repeated courses, credit hours from internship programs, credit hours up to 10 foreign language credit hours for transfer students in Florida, and credit hours earned in military science courses that are part of the Reserve Officers' Training Corps (ROTC) program). This metric is not the same as the Excess Hours Surcharge, which has multiple cohorts with varying fee rates. This table reports the percentage of baccalaureate degrees awarded within $110 \%$ of the catalog hours required for a degree based on the Board of Governors Academic Program Inventory. This calculation is based on Hours To Degree data submitted by universities to the Board of Governors and excludes recent graduates who have already earned a baccalaureate degree. Note*: Improvements were made to data collection process beginning with 2012-13 data to better account for high school dual enrolled credits that are exempt from the excess hour calculation. Also, 2012-13 data marked a slight methodological change in how the data is calculated. Each CIP code's required number of 'catalog hours' was switched to the officially approved hours as reported within the Board of Governors' Academic Program Inventory - instead of the catalog hours reported by the university on the HTD files.

\section{TABLE 4K. Undergraduate Course Offerings}

\begin{tabular}{lccccc} 
& Fall 2009 & Fall 2010 & Fall 2011 & Fall 2012 & Fall 2013 \\
\hline $\begin{array}{c}\text { Number of } \\
\text { Course Sections }\end{array}$ & 2,682 & 2,787 & 2,829 & 2,772 & 2,716 \\
$\begin{array}{l}\text { Percentage of Undergraduate Course Sections } \\
\text { Fewer than } 30 \text { Students }\end{array}$ & $58 \%$ & $62 \%$ & $62 \%$ & $61 \%$ & \\
\hline 30 to 49 Students & $27 \%$ & $24 \%$ & $24 \%$ & $25 \%$ & $26 \%$ \\
\hline 50 to 99 Students & $12 \%$ & $10 \%$ & $10 \%$ & $11 \%$ & $10 \%$ \\
\hline 100 or More Students & $4 \%$ & $4 \%$ & $3 \%$ & $4 \%$ & $4 \%$
\end{tabular}

Notes: This data is based on Common Data Set (CDS) definitions. According to CDS, a "class section is an organized course offered for credit, identified by discipline and number, meeting at a stated time or times in a classroom or similar setting, and not a subsection such as a laboratory or discussion session. Undergraduate class sections are defined as any sections in which at least one degree-seeking undergraduate student is enrolled for credit. Exclude distance learning classes and noncredit classes and individual instruction such as dissertation or thesis research, music instruction, or one-to-one readings. Exclude students in independent study, co-operative programs, internships, foreign language taped tutor sessions, practicums, and all students in one-on-one classes. 


\section{Section 4 - Undergraduate Education (continued)} TABLE 4L. Percentage of Undergraduate Credit Hours Taught by Instructor Type

\begin{tabular}{lccccc} 
& $\mathbf{2 0 0 9 - 1 0}$ & $\mathbf{2 0 1 0 - 1 1}$ & $\mathbf{2 0 1 1 - 1 2}$ & $\mathbf{2 0 1 2 - 1 3}$ & $\mathbf{2 0 1 3 - 1 4}$ \\
\hline Faculty & $65 \%$ & $66 \%$ & $68 \%$ & $66 \%$ & $67 \%$ \\
\hline Adjunct Faculty & $18 \%$ & $16 \%$ & $13 \%$ & $16 \%$ & $15 \%$ \\
\hline Graduate Students & $16 \%$ & $17 \%$ & $18 \%$ & $17 \%$ & $17 \%$ \\
\hline Other Instructors & $1 \%$ & $2 \%$ & $1 \%$ & $1 \%$ & $1 \%$ \\
\hline
\end{tabular}

Note: The total number of undergraduate state fundable credit hours taught will be divided by the undergraduate credit hours taught by each instructor type to create a distribution of the percentage taught by each instructor type. Four instructor types are defined as faculty (pay plans 01, 02, and 22), OPS faculty (pay plan 06), graduate student instructors (pay plan 05), and others (all other pay plans). If a course has more than one instructor, then the university's reported allocation of section effort will determine the allocation of the course's total credit hours to each instructor. The definition of faculty varies for Tables 4L, 4M and 4N. For Faculty Teaching Undergraduates, the definition of faculty is based on pay plans 01, 02, and 22.

\section{TABLE 4M. Student/Faculty Ratio}

\begin{tabular}{cccccc} 
& Fall 2009 & Fall 2010 & Fall 2011 & Fall 2012 & Fall 2013 \\
\hline Ratio & $27: 1$ & $28: 1$ & $27: 1$ & $24: 1$ & $24: 1$
\end{tabular}

Note: This data is based on Common Data Set (CDS) definitions. This is the Fall ratio of full-time equivalent students (full-time plus $1 / 3$ part time) to full-time equivalent instructional faculty (full time plus $1 / 3$ part time). The ratio calculations, exclude both faculty and students in stand-alone graduate or professional programs such as medicine, law, veterinary, dentistry, social work, business, or public health in which faculty teach virtually only graduate-level students. Undergraduate or graduate student teaching assistants are not counted as faculty.

\section{TABLE 4N. Professional Licensure/Certification Exams for Undergraduates}

\begin{tabular}{lccccc} 
Nursing: National Council Licensure Examination for Registered Nurses & & \\
& $\mathbf{2 0 0 9}$ & $\mathbf{2 0 1 0}$ & $\mathbf{2 0 1 1}$ & $\mathbf{2 0 1 2}$ & $\mathbf{2 0 1 3}$ \\
\hline Examinees & 151 & 169 & 210 & 184 & 186 \\
First-time Pass Rate & $96 \%$ & $96 \%$ & $95 \%$ & $93 \%$ & $91 \%$ \\
National Benchmark & $90 \%$ & $89 \%$ & $89 \%$ & $92 \%$ & $85 \%$
\end{tabular}

Note: Pass rate for first-time examinees for the National Council Licensure Examination for Registered Nurses (NCLEX-RN) are based on the performance of graduates of baccalaureate nursing programs. National benchmark data is based on Jan-Dec NCLEX-RN results for first-time examinees from students in US-educated baccalaureate degree programs as published by the National Council of State Boards of Nursing. 


\section{Section 4 - Undergraduate Education (continued)}

TABLE 40. Post-Graduation Metrics

\section{Percent of Bachelor's Graduates Employed Full-time or Continuing their Education, One Year After Graduation}

\begin{tabular}{lccccc} 
& $2008-09$ & $2009-10$ & $2010-11^{*}$ & $2011-12$ & $2012-13$ \\
\hline Percent Found Employed or Enrolled & $\mathrm{n} / \mathrm{a}$ & $\mathrm{n} / \mathrm{a}$ & $\mathrm{n} / \mathrm{a}$ & Data currently available only at \\
Percent Found & $\mathrm{n} / \mathrm{a}$ & $\mathrm{n} / \mathrm{a}$ & $\mathrm{n} / \mathrm{a}$ & the USF System level
\end{tabular}

Notes: Percent Found Employed or Enrolled is based on the number of recent baccalaureate graduates who are either employed full-time or continuing their education within one year after graduation. The employed data now includes non-Florida data that is available from the Wage Record Interchange System 2 (known as "WRIS 2") and Federal employee and military data that is available from the Federal Employment Data Exchange System (FEDES) initiative. Full-time employment is based on those who earned more than a full-time (40hrs a week) worker making minimum wage. Due to limitations in the data, the continuing enrollment data includes any enrollment the following year regardless of whether the enrollment was post-baccalaureate or not. Note*: Non-Florida employment data was not available for the 2010-11 graduates.

Percent Found refers to the percentage of graduates found in the dataset - including those that did not earn wages above the full-time threshold and those who were found outside of the one-year window.

For more information about the methodology see: http://www.flbog.edu/about/budget/performance_funding.php.

For more information about WRIS2 see: http://www.doleta.gov/performance/wris 2.cfm.

For more information about FEDES see: http://www.ubalt.edu/fififedes/.

\section{Median Wages of Bachelor's Graduates Employed Full-time in Florida, One Year After Graduation}

\begin{tabular}{lccccc} 
& $2008-09$ & $2009-10$ & $\mathbf{2 0 1 0 - 1 1}$ & $\mathbf{2 0 1 1 - 1 2}$ & $\mathbf{2 0 1 2 - 1 3}$ \\
\hline Median Wage & $\mathrm{n} / \mathrm{a}$ & $\mathrm{n} / \mathrm{a}$ & $\$ 33,400$ & $\begin{array}{c}\text { Data currently available only at } \\
\text { the USF System level }\end{array}$ \\
Percent Found & $\mathrm{n} / \mathrm{a}$ & $\mathrm{n} / \mathrm{a}$ & $\mathrm{n} / \mathrm{a}$ &
\end{tabular}

Notes: Median Wage data is based on Florida's annualized Unemployment Insurance (UI) wage data for those graduates who earned more than a fulltime employee making minimum wage in the fiscal quarter a full year after graduation. This UI wage data does not include individuals who are selfemployed, employed out of state, employed by the military or federal government, or those without a valid social security number. This wage data includes graduates who were both employed and enrolled. Wages rounded to nearest hundreds. Percent Found refers to the percentage of graduates found in the dataset - including those that did not earn wages above the full-time threshold and those who were found outside of the one-year window. 


\section{Section 5 - Graduate Education}

\section{TABLE 5A. Graduate Degree Program Changes in AY 2013-14}

\begin{tabular}{|c|c|c|c|c|c|c|}
\hline Title of Program & $\begin{array}{l}\text { Six-digit } \\
\text { CIP Code }\end{array}$ & $\begin{array}{l}\text { Degree } \\
\text { Level }\end{array}$ & $\begin{array}{l}\text { Date of } \\
\text { UBOT } \\
\text { Action }\end{array}$ & $\begin{array}{c}\text { Starting } \\
\text { or Ending Term }\end{array}$ & $\begin{array}{l}\text { Date of Board of } \\
\text { Governor's Action }\end{array}$ & Comments \\
\hline \multicolumn{7}{|l|}{ New Programs } \\
\hline Computer Science & 11.0701 & Masters & 12/3/2013 & 2014 Spring & & \\
\hline Cybersecurity & 43.0303 & Masters & 10/23/2013 & 2014 Fall & & \\
\hline $\begin{array}{l}\text { Child and Adolescent Behavioral } \\
\text { Health }\end{array}$ & 44.0000 & Masters & $3 / 6 / 2014$ & 2014 Spring & & \\
\hline Integrative Biology & 26.1399 & $\begin{array}{l}\text { Research } \\
\text { Doctorate }\end{array}$ & 6/20/2013 & 2013 Fall & & \\
\hline Cell and Molecular Biology & 26.0406 & $\begin{array}{l}\text { Research } \\
\text { Doctorate }\end{array}$ & 6/20/2013 & 2013 Fall & & \\
\hline Rehabilitation Services & 51.2314 & $\begin{array}{l}\text { Research } \\
\text { Doctorate }\end{array}$ & 12/5/2013 & 2013 Fall & & \\
\hline \multicolumn{7}{|l|}{ Terminated Programs } \\
\hline Bioethics and Medical Humanities & 51.2301 & Masters & $3 / 6 / 2014$ & 2014 Summer & & \\
\hline Ed of Specific Learning Disabled & 13.1011 & Masters & $3 / 6 / 2014$ & 2014 Summer & & \\
\hline Ed of the Emotionally Handicapped & 13.1005 & Masters & $3 / 6 / 2014$ & 2014 Summer & & \\
\hline Ed of the Mentally Handicapped & 13.1006 & Masters & 3/6/2014 & 2014 Summer & & \\
\hline Biology & 26.0101 & $\begin{array}{l}\text { Research } \\
\text { Doctorate }\end{array}$ & 6/6/2013 & 2013 Fall & & \\
\hline Classics & 16.1200 & Masters & $12 / 5 / 13$ & 2014 Summer & & \\
\hline \multicolumn{7}{|c|}{ Programs Suspended for New Enrollments } \\
\hline 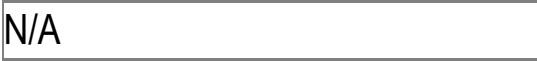 & & & & & & \\
\hline \multicolumn{7}{|c|}{ New Programs Considered By University But Not Approved } \\
\hline N/A & & & & & & \\
\hline
\end{tabular}

Note: This table does not include new majors or concentrations added under an existing degree program CIP Code. This table reports the new and terminated program changes based on Board action dates between May 5, 2013 and May 4, 2014. New Programs are proposed new degree programs that have been completely through the approval process at the university and, if appropriate, the Board of Governors. Does not include new majors or concentrations added under an existing degree program CIP Code. Terminated Programs are degree programs for which the entire CIP Code has been terminated and removed from the university's inventory of degree programs. Does not include majors or concentrations terminated under an existing degree program CIP Code if the code is to remain active on the academic degree inventory. Inactive Programs are degree programs for which enrollments have been temporarily suspended for the entire CIP Code, but the program CIP Code has not been terminated. Does not include majors or concentrations suspended under an existing degree program CIP Code if the code is to remain active on the academic degree inventory and new enrollments in any active major will be reported. New Programs Considered by University But Not Approved includes any programs considered by the university board of trustees, or any committee of the board, but not approved for implementation. Also include any programs that were returned prior to board consideration by the university administration for additional development, significant revisions, or re-conceptualization; regardless of whether the proposal was eventually taken to the university board for approval. Count the returns once per program, not multiple times the proposal was returned for revisions, unless there is a total re-conceptualization that brings forward a substantially different program in a different CIP Code. 
Section 5 - Graduate Education (continued)

TABLE 5B. Graduate Degrees Awarded

\begin{tabular}{lccccc} 
& $\mathbf{2 0 0 9 - 1 0}$ & $\mathbf{2 0 1 0 - 1 1}$ & $\mathbf{2 0 1 1 - 1 2}$ & $\mathbf{2 0 1 2 - 1 3}$ & $\mathbf{2 0 1 3 - 1 4}$ \\
\hline TOTAL (First Majors) & $\mathbf{2 , 7 3 7}$ & $\mathbf{2 , 8 0 0}$ & $\mathbf{2 , 9 4 3}$ & $\mathbf{3 , 0 0 7}$ & $\mathbf{3 , 1 7 9}$ \\
\hline TOTAL (Second majors) & $\mathbf{0}$ & $\mathbf{0}$ & $\mathbf{0}$ & $\mathbf{0}$ & $\mathbf{0}$ \\
\hline Masters and Specialist (first majors) & 2,337 & 2,375 & 2,526 & $\mathbf{2 , 5 5 9}$ & $\mathbf{2 , 6 3 3}$ \\
Research Doctoral (first majors) & 244 & 269 & 271 & 295 & 330 \\
Professional Doctoral (first majors) & 156 & 156 & 146 & 153 & 216 \\
\hline Dentistry & 0 & 0 & 0 & 0 & 0 \\
Law & 0 & 0 & 0 & 0 & 0 \\
Medicine & 116 & 109 & 112 & 106 & 120 \\
\hline Nursing Practice & 10 & 12 & 0 & 5 & 6 \\
Pharmacy & 0 & 0 & 0 & 0 & 0 \\
Physical Therapist & 30 & 35 & 28 & 42 & 90 \\
\hline Veterinary Medicine & 0 & 0 & 0 & 0 & 0 \\
Other & 0 & 0 & 0 & 0 & 0
\end{tabular}

Note: This table reports the total number of graduate level degrees that were awarded by academic year as well as the number by level. The table provides a breakout for the Professional Doctoral degrees.

TABLE 5C. Graduate Degrees Awarded in Areas of Strategic Emphasis [Includes Second Majors]

\begin{tabular}{lccccc} 
& $\mathbf{2 0 0 9 - 1 0}$ & $\mathbf{2 0 1 0 - 1 1}$ & $\mathbf{2 0 1 1 - 1 2}$ & $\mathbf{2 0 1 2 - 1 3}$ & $\mathbf{2 0 1 3 - 1 4}$ \\
\hline STEM & 614 & 648 & 724 & 837 & 929 \\
\hline HEALTH & 615 & 744 & 729 & 762 & 838 \\
\hline GLOBALIZATION & 27 & 27 & 31 & 29 & 25 \\
\hline EDUCATION & 428 & 475 & 496 & 432 & 385 \\
\hline GAP ANALYSIS & 62 & 55 & 66 & 90 & 97 \\
\hline SUBTOTAL & 1,746 & 1,949 & 2,046 & 2,150 & 2,274 \\
\hline PSE PERCENT OF TOTAL & $\mathbf{6 4 \%}$ & $\mathbf{7 0 \%}$ & $\mathbf{7 0 \%}$ & $\mathbf{7 2} \%$ & $\mathbf{7 2 \%}$
\end{tabular}

Notes: This is a count of graduate degrees awarded within specific Areas of Strategic Emphasis, as determined by the Board of Governors staff with consultation with business and industry groups and input from universities. A student who has multiple majors in the subset of targeted Classification of Instruction Program codes will be counted twice (i.e., double-majors are included). Note: The denominator used in the percentage includes second majors. 
Section 5 - Graduate Education (continued)

TABLE 5D. Professional Licensure Exams for Graduate Programs

Medicine: US Medical Licensing Exam - Step 1 (for 2nd year MD students)

\begin{tabular}{lccccc} 
& $\mathbf{2 0 1 0}$ & $\mathbf{2 0 1 1}$ & $\mathbf{2 0 1 2}$ & $\mathbf{2 0 1 3}$ & $\mathbf{2 0 1 4}$ \\
\hline Examinees & 116 & 110 & 125 & 145 & 147 \\
First-time Pass Rate & $97 \%$ & $99 \%$ & $91 \%$ & $96 \%$ & $95 \%$ \\
National Benchmark & $91 \%$ & $94 \%$ & $96 \%$ & $96 \%$ & $96 \%$
\end{tabular}

Medicine: US Medical Licensing Exam - Step 2 Clinical Knowledge (for $4^{\text {th }}$ year MD students)

\begin{tabular}{lccccc} 
& $\mathbf{2 0 0 9 - 1 0}$ & $\mathbf{2 0 1 0 - 1 1}$ & $\mathbf{2 0 1 1 - 1 2}$ & $\mathbf{2 0 1 2 - 1 3}$ & $\mathbf{2 0 1 3 - 1 4}$ \\
\hline Examinees & 128 & 122 & 115 & 152 & 136 \\
First-time Pass Rate & $100 \%$ & $99 \%$ & $99 \%$ & $100 \%$ & $98 \%$ \\
National Benchmark & $97 \%$ & $97 \%$ & $98 \%$ & $98 \%$ & $97 \%$
\end{tabular}

Medicine: US Medical Licensing Exam - Step 2 Clinical Skills (for $4^{\text {th }}$ year MD students)

\begin{tabular}{lccccc} 
& $\mathbf{2 0 0 9 - 1 0}$ & $\mathbf{2 0 1 0 - 1 1}$ & $\mathbf{2 0 1 1 - 1 2}$ & $\mathbf{2 0 1 2 - 1 3}$ & $\mathbf{2 0 1 3 - 1 4}$ \\
\hline Examinees & 116 & 122 & 100 & 128 & 142 \\
First-time Pass Rate & $96 \%$ & $100 \%$ & $98 \%$ & $99 \%$ & $91 \%$ \\
National Benchmark & $97 \%$ & $98 \%$ & $97 \%$ & $98 \%$ & $96 \%$
\end{tabular}

Physical Therapy: National Physical Therapy Examinations

\begin{tabular}{lccccc} 
& $\mathbf{2 0 0 7 - 0 9}$ & $\mathbf{2 0 0 8 - 1 0}$ & $\mathbf{2 0 0 9 - 1 1}$ & $\mathbf{2 0 1 0 - 1 2}$ & $\mathbf{2 0 1 1 - 1 3}$ \\
\hline Examinees & 51 & 81 & 96 & 93 & 92 \\
First-time Pass Rate & $86 \%$ & $85 \%$ & $87 \%$ & $90 \%$ & $94 \%$ \\
National Benchmark & $87 \%$ & $87 \%$ & $89 \%$ & $89 \%$ & $89 \%$
\end{tabular}




\section{Section 6 - Research and Economic Development}

TABLE 6A. Research and Development

2008-09

2009-10

2010-11

2011-12

2012-13

\section{R\&D Expenditures}

Total (S\&E and non-S\&E)

(\$1,000s)

Federally Funded

(\$1,000s)

Percent Funded

From External Sources

Total R\&D Expenditures

Per Full-Time, Tenured,

Tenure-Earning Faculty Member (\$)

\begin{tabular}{ccccc} 
& $\$ 385,029$ & $\$ 394,963$ & $\$ 443,206$ & $\$ 459,409$ \\
\cline { 2 - 5 } & $\$ 243,017$ & $\$ 243,030$ & $\$ 236,148$ & $\$ 225,414$ \\
REPORTED & $\$ 24 \%$ & $63 \%$ & $59 \%$ \\
\cline { 2 - 5 } $\begin{array}{c}\text { AT THE USF } \\
\text { SYSTEM } \\
\text { LEVEL }\end{array}$ & $70 \%$ & $70 \%$ & &
\end{tabular}

$\$ 363,921 \quad \$ 394,963 \quad \$ 433,665$

$\$ 464,049$

\section{Technology Transfer}

Invention Disclosures

U.S. Patents Issued

Patents Issued Per 1,000

Full-Time, Tenured and Tenure-

Earning Faculty

\section{REPORTED AT THE USF SYSTEM LEVEL}

\section{Licenses/ Options Executed}

Licensing Income

Received (\$)

Number of Start-Up Companies

Note: R\&D Expenditures are based on the National Science Foundation's annual Survey of R\&D Expenditures at Universities and Colleges (data include Science \& Engineering and non-Science \& Engineering awards). Percent Funded from External Sources is defined as funds from federal, private industry and other sources (non-state and non-institutional funds). Total R\&D expenditures are divided by fall, full-time tenured/tenure-track faculty as reported to IPEDS (FGCU includes both tenured/tenure-track and non-tenure/track faculty). The fall faculty year used will align with the beginning of the fiscal year, so that (e.g.) 2007 FY R\&D expenditures are divided by fall 2006 faculty. Technology Transfer data are based on the Association of University Technology Managers Annual Licensing Survey. Licensing Income Received refers to license issue fees, payments under options, annual minimums, running royalties, termination payments, amount of equity received when cashed-in, and software and biological material end-user license fees of $\$ 1,000$ or more, but not research funding, patent expense reimbursement, valuation of equity not cashed-in, software and biological material end-user license fees of less than $\$ 1,000$, or trademark licensing royalties from university insignia. Number of Start-up Companies that were dependent upon the licensing of University technology for initiation. 


\section{Section 6 - Research and Economic Development (continued)}

TABLE 6B. Centers of Excellence

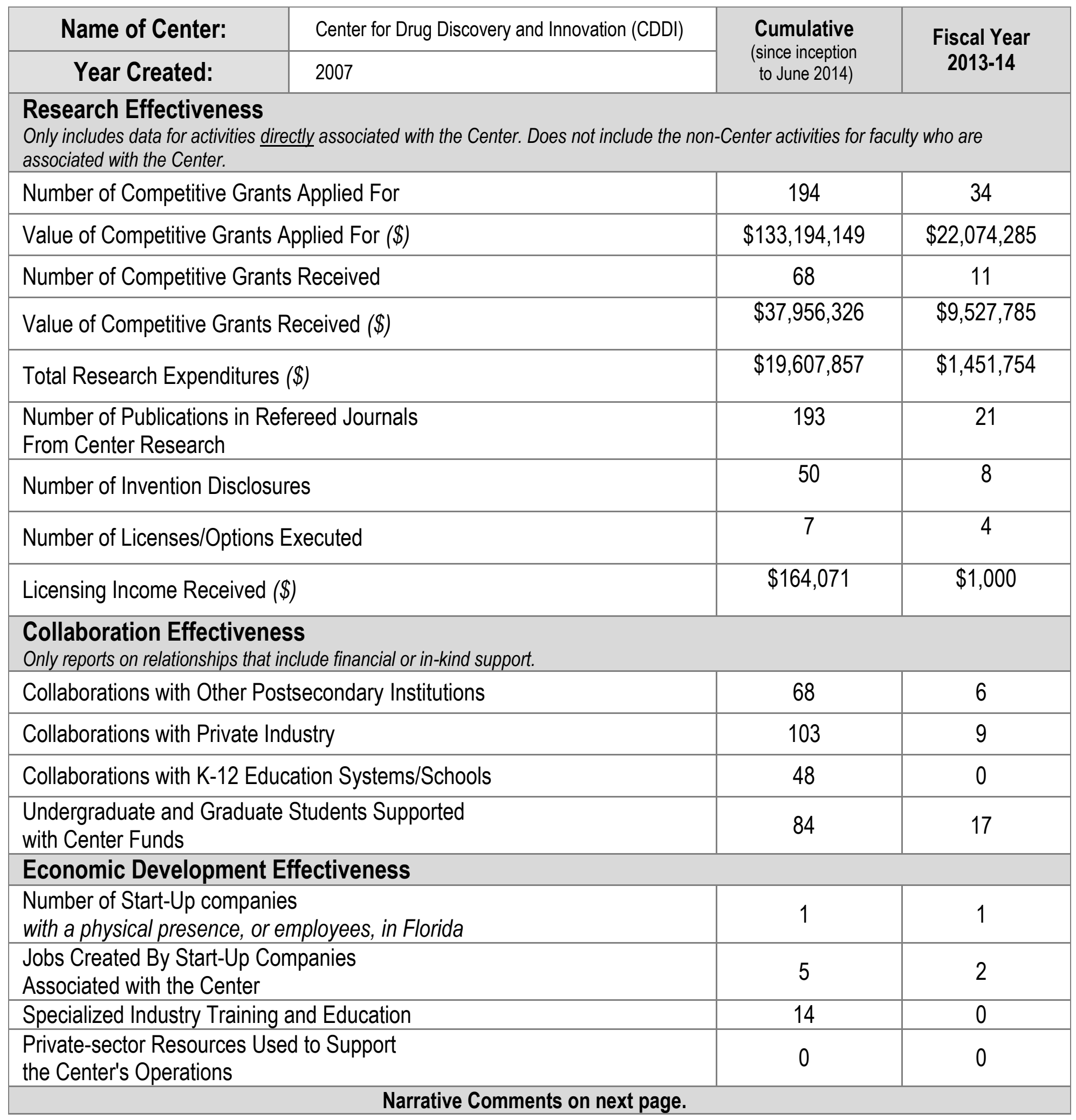




\section{Section 6 - Research and Economic Development (continued) TABLE 6B. Centers of Excellence (continued)}

\section{Name of Center}

Center for Drug Discovery and Innovation (CDDI)

\section{Narrative Comments [Most Recent Year]:}

(1) On December 1, 2013, Dr. Michael White was awarded an NIH 5 year R01 grant totalling $\$ 2,123,111$ to futher research on malarie related diseases. Other CDDI faculty members that are colloborators on this grant includes Assistant Research Professor, Dr. Elena Suvorova and Medicinal Chemist, Dr. James Leahy.

(2) Dr. Bill Baker, Director, CDDI, was awarded a $\$ 1.7$ nmillion grant from NSF to further research on marine ecology in Antartica. This four grant will support the colloborative efforts between the University of South Florida and the University of Alabama at Birmingham.

(3) CDDI recently acquired the latest in benchtop liquid chromatography-mass spectrometry (LC-MS)system for highthroughput screening for its Proteomics Lab. Funds for the purchasing of this new equipment, which cost $\$ 500,000$, were secured through a colloborative effort between USF Research \& Innovation, College of Medicine, College of Arts \& Science, Public Health, Global Health and the Center for Drug Discovery and Innovation. 